\title{
EARLY RETIREMENT, SOCIAL SECURITY AND WELL-BEING IN GERMANY
}

Axel Börsch-Supan and Hendrik Jürges

๑ $\boldsymbol{M e a - M a n n h e i m ~ R e s e a r c h ~ I n s t i t u t e ~ f o r ~ t h e ~ E c o n o m i c s ~ o f ~ A g i n g ~}$

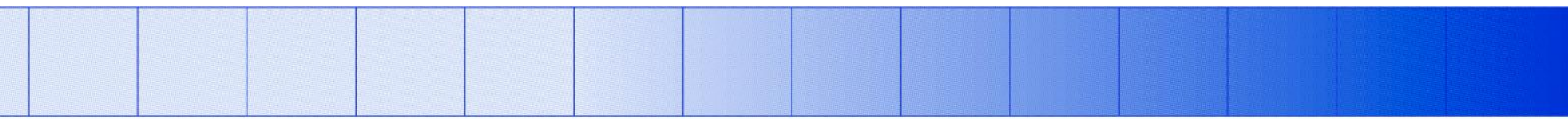

L13, 17_D-68131 Mannheim_Phone +49 621 181-2773/1862_Fax +49 621 181-1863_www.mea.uni-mannheim.de 


\title{
Early Retirement, Social Security and Well-Being in Germany
}

\author{
Axel Börsch-Supan* and Hendrik Jürges** \\ * Mannheim Institute for the Economics of Aging (MEA), University of Mannheim \\ and National Bureau of Econommic Research (NBER), Cambridge, Mass., USA \\ **Mannheim Institute for the Economics of Aging (MEA), University of Mannheim
}

\begin{abstract}
Germans retire early. On the one hand, early retirement is very costly and amplifies the burden which the German public pension system has to carry due to population aging. On the other hand, however, early retirement is also seen as a much appreciated social achievement which increases the well-being especially of those workers who suffer from work-related health problems.

This paper investigates the relation between early retirement and well-being using the GSOEP panel data. The general picture that emerges from our analysis is that early retirement as such seems to be related to subjective well-being, in fact more so than normal retirement. Early retirement most probably is a reaction to a health shock. Individuals are less happy in the year of early retirement than in the years before and after retirement. After retirement, individuals attain their pre-retirement satisfaction levels after a relatively short while. Hence, the early retirement effect on well-being appears to be negative and short-lived rather than positive and long. Whether this is an effect of retirement itself or a psychological adaptation to an underlying shock cannot be identified in our data and remains an open research issue waiting for a more objective measurement of health.
\end{abstract}

\author{
Address \\ MEA, L13, 17 \\ University of Mannheim \\ D-68131 Mannheim, Germany \\ Email: axel@boersch-supan.de,juerges@mea.uni-mannheim.de.
}

ACKNOWLEDGEMENTS: This paper is part of phase 4 of the NBER's International Social Security Project. Financial support was provided by the National Institute on Aging through the NBER Grant No. P01-AG05842 and by the DFG through Sonderforschungsbereich 504. We are also grateful for financial support by the State of Baden-Württemberg and the German Insurers Association (GDV). 


\section{Early retirement, social security and well-being in Germany}

by Axel Boersch-Supan and Hendrik Jürges

\section{Introduction}

Germans retire early. While the statutory “normal” retirement age for men and women is age 65 , the actual average retirement age is much earlier. Only about $20 \%$ of all entrants used the "normal" pathway of an old-age pension at age 65. The most popular retirement age is age 60 . The average retirement age in 1999 was 59.7 years for men and 60.7 years for women. These numbers refer to West Germany. In the East, retirement age was 57.9 years for men and 58.2 years for women.

Early retirement is popular. It is seen as a much appreciated social achievement which increases the well-being especially of those workers who suffer from work-related health problems. The 1972 reform in Germany which introduced early retirement without actuarial adjustment in the benefits was a great political success.

But times have changed. With an increasingly aging population and the precarious financial state of the public pension system, the costs of early retirement have received increased scrutiny. The German social security contribution rate, in 2003 at 19.5 percent of gross income, was projected in the mid 1980s to exceed 30 percent of gross income at the peak of population ageing in 2035 if the accustomed benefits (i.e., eligibility age and replacement rate) were maintained. ${ }^{1}$ This led to a string of pension reforms since 1992 effectively bidding farewell to the pure pay-as-you-go system and introducing a multipillar pension system with two funded pillars of occupational and individual pensions in addition to the traditional unfunded retirement insurance.

These reforms did, however, only timidly touch the early and not at all the normal retirement ages which were age 60 and age 65, respectively. Bearing increasing life expectancy in mind, raising the age of retirement would appear to be an obvious reform option. The introduction of modestly actuarial adjustments in the 1992 reform was delayed by almost 10 years because of its unpopularity. Only recently, as part of the proposals of the "Rürup-Commission", the reform discussion has shifted once again to the pivotal "normal” retirement age as a means to reduce early retirement and shift the average retirement age a few years forward.

\footnotetext{
${ }^{1}$ See Börsch-Supan $(1998,2000)$ for a description of the problems plaguing the German public pension system.
} 
This paper is the forth in a string of studies on early retirement in Germany which are accompanied by sister studies in other OECD countries as part of the International Social Security Project coordinated by Jonathan Gruber and David Wise. In the first stage (BörschSupan and Schnabel, 1998 and 1999), we described and quantified the incentives to retire early in the form of "implicit taxes" on continued work.

The second stage (Börsch-Supan, Schnabel, Kohnz and Mastrobuoni, 2004; Berkel and Börsch-Supan, 2004) provided econometric estimates of the strength of incentive effects on old age labor supply, using several specifications of incentive variables. These highly significant and large estimates were used to simulate labor force participation responses to several policy changes. For instance, introducing (almost) actuarially fair adjustments (6\% per year of delay) would increase the average retirement age of German men by about 3 years and 2 months. The effects are about half the size for women.

In the third stage, Börsch-Supan, Kohnz and Schnabel (2004) used these estimates and converted them into budget effects on the German public pension system. They simulated the impact of several stylized reform plans on older workers' net fiscal contributions to the finances of the German public pension system, distinguishing between a direct effect by changing contributions and benefits for a given work history (a purely “mechanical” effect) and an indirect effect through labor supply responses to the reform (a "behavioral" effect). The paper finds very large cost implications of early retirement. For instance, the unpopular introduction of a $6 \%$ per year actuarial adjustment would imply a reduction of pension expenditures for a typical cohort by $18 \%$ in direct benefit reductions and by an additional 26\% through labor supply responses.

This fourth stage changes the point of view and looks at the benefits of these large costs. The immediate benefit from early retirement is income support without the necessity to continue working. This should directly benefit those workers who feel strained e.g. due to workimpeding health problems, and should manifest itself in an improvement of well-being. This paper therefore uses available measures of well-being and applies various difference-indifference methods to elicit the response of well-being to early and normal retirement.

Research on these issues is difficult since the measures of health which are commonly available in general purpose survey may suffer from the very same justification bias as measures of well-being do (Bound, 1991). We therefore need exogenous variation separating the effects on health and well-being. Unfortunately, we cannot follow the same strategy as the 
other papers in this volume which are able to exploit institutional variation (changes in the generosity of the social security system) that affects different cohorts differently.

There are two reasons why this approach does not work well in Germany. First, the last observable major change in program generosity which affected cohorts differently was the 1972 reform where several early retirement options were introduced. However we don't have good data on most key variables before and during the 1970s. The recent string of pension reforms mentioned above does also affect cohorts differentially, but the effects are too recent to be reflected in the currently available data.

Second, most program changes that have been happening in Germany between 1972 and 2001 (e.g. the switch from gross to net wage indexation in 1992) have affected everyone who is receiving benefits in equal proportion. Hence, there is no differential impact on cohorts. This can be most easily seen by looking at the German pension benefit formula which defines the benefits of pensioner $\mathrm{i}$ in year $\mathrm{t}$ :

$B_{t, i}=P V_{t} * E P_{i} * A A_{i}$

where

$P V_{t}=$ Current pension value in year $t$,

$E P_{i}=$ Number of individual earnings points collected by pensioner $i$ until his retirement $A A_{i}=$ Actuarial adjustment, dependent on the retirement age of pensioner $i$.

Benefits therefore have a simple structure: an individual component $E P_{i} * A A_{i}$ determined by each persons earnings history and retirement age which stays fixed for the entire retirement period, and an aggregate component $P V_{t}$ which adjusts benefits over time equally for all pensioners. $E P_{i}$ represents the "point system" and $A A_{i}$ is determined by actuarial accounting rules, see e.g. Börsch-Supan and Wilke (2003). A typical worker who works for 40 years and earns the average wage receives 40 earnings points. If this worker retires at age 65 , no actuarial adjustments take place $(A A=1)$. In the second half of 2002, the current pension value $P V_{t}$ was 25.86 Euro. Hence this typical worker receives a pension of 1034.40 Euro per month.

Each year, currently at July 1 , the current pension value $P V_{t}$ is recalculated with the aid of the benefit indexation formula. Until recently, this benefit indexation formula was essentially a simple indexation rule to the average annual level of wages and salaries (before 1992: gross wages and salaries, after 1992 net wages and salaries). From the year 2005 on, it will also include an indexation to the system dependency ratio (the number of full-time equivalent pensioners divided by the number of full-time equivalent employees who contribute to the system). 
Since the current pension value $P V_{t}$ has a direct influence on every individual pension, the benefit indexation formula is a critical determinant for the well-being of pensioners and the amount of money spent by the public pension scheme. However, it does not differentiate among cohorts. The individual component $E P_{i} * A A_{i}$ is not affected by the recent string of reforms, ${ }^{2}$ and the change in the current pension value $P V_{t}$ is a pure time effect. As opposed to many other public pension systems, the German system so far does not differentiate between the existing stock of pensioners and the new entrants. ${ }^{3}$

In this paper, we therefore try to follow another route to identification and study long-term development in subjective well-being or overall life satisfaction before and after retirement, conditional on retirement age. We try to answer whether early retirement is beneficial for the individual in terms of overall life satisfaction, that is we ask if the effect of retirement on well-being is more favorable for those taking early retirement than for those taking retiring at the normal retirement age. Put differently, we attempt to compare the well-being of those collecting early retirement benefits versus those in some other status.

Retirement as such (independent of the age at which someone retires) might be beneficial because individuals are able to enjoy more leisure. It might as well be harmful because individuals who stop working may lose a purpose in life. In any case, the effect of early retirement can only be evaluated properly if compared with normal retirement.

Of course, an individuals retirement age is not endogenous. It depends on several factors institutions, health, labor force status of spouse, etc. When we study the effect of retirement on well-being, we thus face the usual task to disentangle cause and effect. For example, persons in bad health are likely to retire earlier but also to report worse life satisfaction. Those who hope or believe that life satisfaction will increase after retirement are more likely to retire at any age. So we are facing a typical evaluation problem. Clearly, in a situation where individuals can choose freely when to retire, we should expect individuals who gain most from early retirement to be those who are most likely to retire early.

The econometric problem is to find a counterfactual value for life satisfaction had a person not taken early retirement. Aggregated across all early retirees we would then have an "estimate" of the intangible benefits of early retirement.

\footnotetext{
${ }^{2}$ There are subtle changes in the computation of earnings points, especially the extent to which higher education contributes to the points. They are too subtle to be reflected in the GSOEP data.

${ }^{3}$ An exception is the recent change in early retirement rules. They will provide a potentially very helpful instrument to follow the approach taken in the other papers in this volume. We will, however, have to wait for another few years to see the effect in micro data sets such as SHARE or GSOEP.
} 
The common belief seems to be that early retirement is beneficial at least to those who retire early, because individuals make use of what is mostly described as "generous" retirement incentives. This view assumes that early retirement is always voluntary, that it is the choice of the retiree. But of course, this need not be the case. Think of a 58 year old worker who becomes unemployed. In Germany, re-employment chances at this age are bleak. The worker will probably stay unemployed and draw unemployment benefits until he turns 60 and then "retire", i.e. receive social security payments instead of unemployment insurance.

It is a priori unclear whether early retirees should be better off than those retiring at the normal retirement age. We distinguish three kinds of arguments:

- Early retirees suffer from retirement (compared to normal retirees) because they are forced out of the labor force by employers, i.e. early retirement is at least to some extend involuntary. If someone who retired early was given the opportunity to retire later, he or she would enjoy an increase in well-being. A normal retiree forced to retire earlier would suffer a well-being loss.

- Early retirees benefit from retirement (compared to normal retirees) because they can make use of generous early retirement incentives (somehow limited; not available to everyone). As a consequence, they experience an increase in well-being that is larger than the corresponding increase of those who take normal retirement. If someone who retires early was forced to retire later, he or she would suffer a well-being loss. A normal retiree allowed to retire earlier would enjoy a well-being increase.

- There is no difference between early and normal retirement because both types of individuals have chosen retirement optimally. If someone who retired early was forced to retire later, he or she would suffer a well-being loss. A "normal" retiree forced to retire earlier would suffer a well-being loss, too.

We build our study on two strands of literature. One strand studies the relationship between labor market events and life satisfaction. Winkelmann/Winkelmann (1998) show that unemployment reduces well-being. They employ the GSOEP panel, such as this panel, and use conditional logit models. Clark et al. (2003) study the set point model of happiness: demographic events (marriage, divorce, birth of first child) and labor market events (unemployment, layoff, and quitting a job) with GSOEP data. The set point model assumes that individuals return to initial levels of well-being after some time. Their results are that the strongest life satisfaction effects often appear at the time that the events in question occur. 
However, there are both significant lag and lead effects. For some events, there is rapid return to baseline satisfaction, while others have a lasting effect. Their focus is on respondents aged 19 to 59 , somewhat younger than our sample.

Another strand of the literature studies retirement, in particular the effect of retirement on mental health, depression, etc. Retirement - the end of working life - is a major change in everyone's life. Some studies have found psychological well-being increases after retirement, others have found that it drops. Charles (2002) studies the effect of retirement on depression, while Lindeboom et al. (2002) study the effect of retirement, a significant decrease in income, death of the spouse, disability, and a move to a nursing home on the mental health of elderly individuals, using data from the Longitudinal Aging Study Amsterdam (LASA). Measures for the dependent variable are the mental health and depression scales MMSE and CES-D.

Convincing causal studies are rare. Psychologists have largely ignored the problem of causation. It is in fact difficult to find e.g. instruments that can be useful in this context. For example, health status is a major factor in the retirement decision but health certainly influences life satisfaction

\section{Early retirement incentives in Germany}

The generosity of the German public pension system in terms of early retirement possibilities and financial incentives to retire early has changed quite a bit during the last 30 years (see Table 1 for a list of major changes). Until 1972, the public pension system was very inflexible and permitted retirement only at age 65. The only exception were disabled workers which, however, made up for roughly 50 percent of new retirement entries. The 1972 pension reform changed this dramatically by introducing the opportunity to retire at different ages („flexible retirement“) during a „window of retirement.“ This window began at age 60 for women, unemployed, and workers who could not appropriately be employed for health or labour market reasons. It began at age 63 for workers with a long service history (35 years, including higher education, military service, a certain number of years for rising children, etc.). Normal retirement age was (and still is) age 65. The 1972 reform did not introduce an actuarial adjustment. The reforms in the 1990s will shift the window of retirement for all workers to age 62 and will include an adjustment of benefits, although this adjustment will remain less than actuarially fair, see below.

<about here Table 1: Trends in Program Generosity> 
The introduction of early retirement had a huge impact on retirement age. Within a few years, retirement age among men dropped by about 3 years, see Börsch-Supan and Schnabel (1998). The average retirement age fell below age $60 .^{4}$ The resulting distribution of retirement ages became marked by distinct „spikes“ at ages 60, 63 and 65, see Börsch-Supan and Schnabel (1999). The retirement age of 65 now mostly applies to women with a very short earnings history, while the most popular retirement age among men became age 60 . Since average life expectancy of a male worker at age 60 is about 18 years, the earlier retirement age amounts to an increase in pension expenditures of about 15 percent. The effect is smaller, but still significant, for women.

Until recently, there was no adjustment of benefits to retirement age. ${ }^{5}$ However, because benefits are proportional to the years of service, a worker with fewer years of service would get lower benefits. With a constant income profile and 40 years of service, each year of earlier retirement decreased pension benefits by 2.5 percent, and a postponement of retirement vice versa. The 1992 reform introduced retirement age-specific adjustment factors. These actuarial adjustments add $3.6 \%$ to the above $2.5 \%$, and are therefore lower than required for incentive neutrality, see Berkel and Börsch-Supan (2004). The system before the 1992 reform was particularly distortive in rewarding early retirement. As opposed to workers e.g., in the United States, which have no incentive to retire before age 65 and only a small disincentive to retire later than at age 65 (see Diamond and Gruber, 1997), the German social security system tilts the retirement decision heavily towards the earliest retirement age applicable. The 1992 pension reform in Germany has diminished but by no means abolished this incentive effect.

The failure to adjust benefits in an actuarially fair manner creates a loss in unfunded social security wealth when a worker postpones retirement. This loss has been computed by BörschSupan and Schnabel (1998). It is large relative to the labour income that could be earned when working longer. This loss can thus be interpreted as an implicit tax on earnings when postponing retirement. This implicit tax exceeded 50 percent before the 1992 pension reform and will still be in excess of 20 percent in 2004 when the 1992 reform will have been fully phased in.

Several formal econometric analyses have studied the incentive effects of the non-actuarial adjustment on early retirement. These studies employ variants of the microeconometric option

\footnotetext{
$4 \quad$ Averaged over new recipients of old-age and disability pensions. Results for women are similar. $5 \quad$ Curiously, the German system before 1992 provided a large increase in retirement benefits for postponing work at ages 65 and 66. However, this incentive was ineffective because the inducements to early retirement by far offset it.
} 
value analysis developed by Stock and Wise (1990). Börsch-Supan, Schnabel, Kohnz and Mastrobuoni (2004) derives from their estimates that the 1992 reform will increase the average retirement age only by about half a year, and reduce retirement before age 60 from 32 percent to about 28 percent, while a switch to a system with actuarially fair adjustment factors would shift the retirement age by about two years.

\section{Trends in program generosity and the well-being of the elderly population}

In this section we examine whether there is a direct relationship between the generosity of the social security system, measured as real total social security expenditures divided by the size of the population aged 55 and older, and the economic and psychological well-being of the elderly. Figure 1 shows the evolution of average social security expenditure since 1960 both in absolute terms and its growth rate on one year earlier. The graph shows a break in 1978, when the growth of the average public pensions virtually ceased. The average growth rate between 1960 and 1978 was 6.1 percent, after 1978 the average went down to 0.8 percent. There are 7 years in which real growth rates have been negative.

$<$ about here Figure 1>

We study the effect of the program generosity on the various key dimensions of well-being: income, expenditures, poverty rates, general life satisfaction, self-reported health, and mortality. Measures for these dimensions dependent variables are derived from various data sources (see Table 2 for an overview). Unfortunately, since the main data source is the GSOEP, we do not have much data before 1984. Our possibilities to study public pension reforms before 1984 are thus very limited.

$<$ about here Table 2>

Our basic method to examine effects of program generosity is a variant of the difference-indifferences approach. We split our samples in two groups: and old (aged 55+) and young (aged 25 to 49). For both groups we first calculate first differences (annual growth rates) in our key measures. Then we calculate the difference between first differences of the old and the young population, which gives us the relative change in well-being of the elderly. Finally, this measure is regressed on the change in program generosity, i.e. the annual growth rate in average social security expenditures as shown in Figure 1. 
Figure 2 contains the relative income growth, separately for elderly men and women, together with annual growth rate in social security expenditures (dashed line). The first impression is that a couple of ups and downs of both measures coincide, so that there might indeed be some association between the two measures. However, the correlation coefficients are not significantly different from zero and they have different signs for men and women. On this rather descriptive level, it is not possible to find an effect of social security expenditures on the well-being of the elderly.

$<$ about here Figures 2, 3, 4

This also holds in Figure 3, where we show the five year growth rates in total household expenditures of old relative to young households. The correlation between this measure and the five year growth rate in social security expenditures is actually negative. Figure 4 shows the development of the old population's poverty rate relative to the young population's poverty rate. The negative correlation coefficient indicates that social security expenditures decrease old relative to young poverty. However, the relationship is not significant.

$<$ about here Figures 5 and 6>

Figures 5 and 6 show the development of two different measures of overall subjective wellbeing or happiness. Figure 5 contains Eurobarometer results. The Eurobarometer life satisfaction scale is a four point Likert-scale with answer categories "very satisfied", "fairly satisfied", "not very satisfied", "not at all satisfied". Here we show the proportion of respondents who claim to be "very satisfied" with their lives. There seems to be an astonishing close relationship between social security expenditures and the well-being of both young and old, at least until 1990. When we calculate the difference in well-being between the young and the old, or the difference in changes in well-being, the correlation between social security expenditures and the well-being of the elderly vanishes. Moreover, using the Welfare Survey and the GSOEP as alternative data sources on well-being, it is not possible to replicate the Eurobarometer results. Both survey use the same eleven point scale from 0 ("not at all satisfied") to 10 ("completely satisfied") to elicit information on general life satisfaction. Figure 6 shows the proportion of with a value of 9 or 10 on this scale. In contrast to the Eurobarometer results, life satisfaction decreases more or less continuously in both age groups since 1978. The reason for this difference is unclear. Possible reasons are differences in sampling, interview modes, question contexts, etc. between the different surveys. It is clearly beyond the scope of the present paper to provide an explanation for what is probably a 
survey artefact. In the analysis presented below, we will use GSOEP data only, i.e. consistent data from a single source.

$<$ about here Figures 7 and $8>$

Our final measures of well-being are self-reported general health and life expectancy. Selfreported health is available in the GSOEP only since 1992 and it is measured on the WHOforrmat 5 point Likert scale with values from "very good" to "very bad". Figure 7 shows the old minus young difference in the proportion of respondents who claim that their health is "very good", "good", or "fair", separately for men and women. For example, a value of -0.2 mean that proportion of individuals in fair or better health is 20 percentage points higher among the young than the among the old. We observe no significant relationship between social security expenditures and self-reported health.

Figure 8 shows annual changes in life expectancy at age 55, separately for men and women.. Again, some ups and downs in life expectancy and social security expenditures seem to coincide. In particular after 1980, there is a positive correlation (roughly 0.4 for both sexes). However, considering the entire period from 1960 to 2000, the correlation is slightly negative.

\section{Early retirement and the well-being of retirees}

The data used in this and the following sections are exclusively drawn from the German Socio-Economic Panel (GSOEP) and cover the years 1984-2002. Our subsample consists of all West German employees who retire during the observation period at an age of between 55 and 65, where retirement is defined by the receipt of benefits, and who are between 50 and 69 years old. We have a reasonable number of observations (see Table 3).

$<$ about here Table 3>

The GSOEP contains information on a large number of household and individual characteristics as well as the respondents' overall life satisfaction and satisfaction with aspects of their lives. The core of six aspects mentioned in each survey year consists of health, household income, job (if employed), housework (if respondent is looking after home or family), leisure time, and dwelling. Responses are all on a scale from 0 to 10 , where 0 means "not satisfied at all" and 10 means "completely satisfied". The satisfaction data in the GSOEP is unique in that it provides comparable data over a long period. It has been found to be very 
useful in a number of studies (e.g. Winkelmann/Winkelmann 1998, Clark et al. 2003, Jürges, 2003)

Our main dependent variable - subjective well-being - is measured on an ordinal scale. Ideally, we would account for this fact statistically in an ordered response framework. In repeated cross-sections this would be straightforward. However, with panel data, it seems natural to take advantage of the possibility to account for unobserved individual heterogeneity such as individual reference levels for life satisfaction. Estimation of ordered probability models with random effects is straightforward but the random effects model is very restrictive as it assumes zero correlation between the individual effect and observed characteristics. We have good reason to suspect that this assumption is violated in the present application, because the Hausman test applied to the linear random and fixed effects models rejects the random effects specification at a very high significance level. A fixed effects model should therefore deserve more trust than a random effects model. Greene (2001) recently showed how to avoid the computational difficulties associated with non-linear fixed effects models, so that estimation of a fixed effects ordered probit model would be feasible. However, even with up to 19 observations for each individual, the inconsistency of the individual effects (the incidental parameter problem) carries over to the slope parameters. This does not hold for the linear fixed effects regression.

In the following analyses, we follow a different approach to account for the ordinal nature of the subjective well-being variable. We applying the "empirical normal transformation" to the life satisfaction index (see van Praag and Baarsma (2001)). This transformation replaces the index values $\mathrm{k}$ on the life satisfaction index from 0 to 10 by numbers

$$
k^{*}=N^{-1}[\text { cum.p }(k-1)+0.5 p(k)]
$$

where $\mathrm{N}$ denotes the standard normal distribution, cum.p $(k-1)$ is the proportion of respondents with life satisfaction less than $k$, and $p(k)$ is the proportion of respondents with life satisfaction equal to $k$. $k^{*}$ approximately has mean 0 and standard deviation 1 . Parameters can thus (again, approximately) be interpreted in terms of standard deviations. ${ }^{6}$

$<$ about here Figure 9>

Figure 9 shows the development of subjective well-being over time for both men and women. It is more or less a replication of Figure 6. Although there are some minor differences

\footnotetext{
${ }^{6}$ The obtained results are similar those without transformation (except of course for the different scaling), but the statistical fit is slightly better.
} 
between the sex, the overall pattern is the same: from 1984 to 1987, well-being declines sharply. Between 1990 and 1992, there is a characteristic “reunification-hump”. Well-being then falls until 1995 below the pre-reunification level and remains fairly constant with some ups and downs afterwards. While we also find the reunification hump in alternative sources that measure well-being over a longer period (e.g. the Eurobarometer, see Figure 5 above), it is unclear why we find the sharp decline in the first couple of years of the GSOEP. Part of this trend might be a panel artefact. Respondents seem to overstate satisfaction levels in the first waves of the GSOEP relative to later waves (see e.g. Landua (1993), Schräpler (2001) or Jürges (2003)). Two reasons for this finding come into mind. First, respondents initially might not be willing to reveal their "true" level of dissatisfaction. In later waves, when the interviewer and the interview situation become familiar to the respondents, this kind of bias might vanish. Second, the satisfaction scales have end points. Respondents might learn that once they have stated the highest satisfaction level, they have no means to express improvements in satisfaction and that it is only possible to convey equal or less satisfaction. Second or third time respondents could therefore "adjust" their answers downward in order gain the flexibility to state improvements in life). Repeated measurement effects can also be found for health, income and job satisfaction measured in GSOEP.

Since the aggregate movements of average life satisfaction in the GSOEP are quite strong, they potentially influence our results. For this reason, we use de-trended satisfaction data, whenever possible. ${ }^{7}$ One potential drawback of de-trending is that certain types of comparisons are no longer possible, for example comparisons that exploit institutional variations over time. However, between 1984 and 2002, variations in the German public pension system have been minimal. As mentioned above, the immediate effects of the 1992 reform (change from gross to net wage indexation) applied to everyone (independent of retirement age). The other changes are currently - i.e. ten years after the reform - phased in slowly.

$<$ about here Figure 10>

Figure 10 describes well-being by age for retired and non-retired individuals. While life satisfaction appears to be quite stable among males and females who are not retired, it shows a strong increase among the retired up to about age 60. The initial gap (at age 55) is between .5 standard deviations for males and 1 standard deviation for females, and decreases to about

\footnotetext{
${ }^{7}$ We de-trend the data by subtracting the difference between the annual average and the overall average from each individual's value in the respective year.
} 
.1 standard deviations and zero, respectively. How can the result in Figure 10 be interpreted? Are those who retire early becoming unhappy (the earlier the worse) or are those who are unhappy before age 60 more likely to retire?

To answer this question, it is instructive to compare the development of life satisfaction from age 50 to age 69 for individuals who retire at different ages. For each sex, we will distinguish four different groups of retirees (see Table 4).The first group consists of men or women retiring at age 55 to 59 and who are legally disabled in the year of retirement, thus receiving disability pensions. Workers are defined as legally disabled if their capacity to work is reduced by at least 30 percent. The second group consists of all other of men or women retiring at age 55 to 59. The third group of men consists of those who retire between age 60 and 62. These are men who receive old-age pensions following unemployment or disability. The third group of men retires at 63 or later, usually receiving normal old-age pensions. A large proportion of women retires at age 60 . This is the normal retirement age for women with an employment history of more than 15 years. The third group of women are those retiring at age 61 or later. These are women with short employment histories.

$<$ about here Table $2>$

The following figures describe the development of some key well-being indicators from four years before retirement to four years after retirement, separately for men and women and for each of the four sub-groups described in Table 2. Figure 11 shows the proportion of respondents who are fairly to very happy (defined as having a value of between 5 and 10 on the life satisfaction index) and average life satisfaction. Even in this simple descriptive graph, there are a number of interesting findings. Early retirees are less happy than normal retirees both before and after retirement. The most unhappy group are those who retire early and are disabled at retirement. It seems as if they are on a much lower life satisfaction level throughout the entire 9-year interval. For example, the proportion of men who retire on DI before they are 60 and who are at least fairly happy is on average somewhat more than 85 percent (see top left panel). The same proportion among those who retire between age 60 and 65 is about 95 percent. Put differently the proportion of unhappy respondents is roughly three times as high among the disabled retiring before age 60. Turning to average life satisfaction (top right panel), we see that those who retire at the "normal" age are the most happy throughout the entire 9 year period. Again, the least happy are early retirees who are legally disabled. Among females, the results are similar to men. The only difference is that women 
who retire before age 60 and who are not disabled at that time are continuously less happy than those retiring later.

<about here Figure 11>

Another interesting feature of Figure 11 is that life satisfaction trough in the year of retirement found for the DI retirees. Among men, this is the only group of retirees that shows systematic developments in well-being around retirement age. The proportion of unhappy respondents almost doubles in the retirement year. We also see some anticipation effect, as the well-being decrease already starts one year before retirement. But being unhappy does not seem to last long. One to two years after retirement, happiness among the disabled early retirees is back to the initial level. The results for women are basically similar to those for men. Happiness hits an all-time low in the year of retirement only among early retirees, but individuals mostly seem to recover quickly. To summarize, while leaving work as such does not increase the proportion of unhappy respondents, it is associated with lower well-being levels of early retirees. Of course, the causal direction of this relationship remains unclear.

$<$ about here Figure 12>

Figure 12 describes the development of a number of disability status, self-reported general health, and per capita household income. Merely by definition, we find large and increasing proportion of legally disabled respondents among those who retire early and are disabled at retirement. As with life satisfaction, we see a clear difference in health levels between those who retire early (presumably on disability pensions) and those who retire at the normal age. While more than 80 percent of those who retire at age 63 or later report being in fair or better health, the corresponding proportion among disabled early retirees is between 20 and 60 percent. Note that we do not control for age in the sense that individuals are compared at the same age. Early retirees are in fact younger, so that controlling for age would lead to even larger health differences.

What is even more striking than the differences in levels are health trends before and after retirement. The disabled early retirees experience gradually declining self-reported health until they retire. The proportion of respondents in "fair" to "very good" health declines from 60 percent 3 years before retirement to slightly more than 20 percent at retirement. However, after retirement, health gradually improves and the proportion of those who are at least in "fair" health is back to nearly 50 percent. Among the other subgroups, self reported health shows only small and probably unsystematic movements. 
The right column of Figure 12 shows log per capita household income before and after retirement. Income decreases after retirement in all sub-groups except women who retire at age 60 .

\section{Estimating the effect of early retirement on well-being}

\subsection{Estimation}

As pointed out earlier. Germany has no good natural experiments that could be exploited for our purpose. We therefore start by simple before-after comparisons covering four years before and after retirement, separately for the eight different subgroups, and then follow with more elaborate difference-in-difference methods and their variants.

For Simple before-after comparisons we estimate

$$
y_{i t}=\sum_{t=-4}^{4} \delta_{t}+\gamma Z_{i t}+c_{i}+\varepsilon_{i t},
$$

where $t=0$ is the year of retirement and we restrict $\delta_{0}=0$ to avoid dummy variable trap. $\delta_{t}$ thus measures the well-being differential between year $t$ and the year of retirement. These estimates serve to illustrate how subjective well-being behaves around retirement age for different parts of the population. $c_{i}$ captures a lot of individual heterogeneity, e.g. a baseline satisfaction level. Others have explicitly modeled baseline satisfaction (Clark et al. 2003) by taking the average of life satisfaction before the observation period (i.e. 7 to 5 years before the event under study). The disadvantage of this procedure for our study is obvious: All individuals that retire within the first four years of the GSOEP would drop out of the analysis. As mentioned above, we use disability status and income as control variables $Z$.

We then continue by estimating differences-in-differences, that is we compare the before-after estimates obtained in the first stage. For the sake of exposition let us assume there are only two types of individuals, early and normal retirees. We pool both types of individuals and estimate:

$$
y_{i t}=\sum_{t=-4}^{4} \delta_{t}+\sum_{t=-4}^{4} \beta_{t} R_{i}+\gamma Z_{i t}+c_{i}+\varepsilon_{i t}
$$

where $R_{i}$ indicates early retirement of individual $i$. We restrict $\delta_{0}=\beta_{0}=0$, that is all differences in well-being levels between early and normal retirees at the age of retirement are 
absorbed by $c_{i}$, the individual component. $\beta_{t}$ thus measures the double difference in wellbeing

$\beta_{t}=\left[E\left(y_{t} \mid R, Z\right)-E\left(y_{0} \mid R, Z\right)\right]-\left[E\left(y_{t} \mid R, Z\right)-E\left(y_{0} \mid R, Z\right)\right]$

\subsection{Results}

Figures 13 and 15 show the set of simple before-after comparisons of average life satisfaction (based on fixed effects models). The graphs show average subjective well being relative to $t=$ 0 , the year of retirement, together with the limits of a $90 \%$ confidence interval. The control variables used are log per capita household income and individual disability status as a measure of health.

<about here Figures 13 and 14>

Let us first consider Figure 13, which contains the results for men. The top left panel shows that the life satisfaction of those who are younger than 60 and legally disabled at retirement increases by about .2 standard deviations after retirement and more or less remains at that level also in the following years. The increase is significant at the 10 percent level. Compared to the year of retirement, early retirement thus had a positive effect on the well-being of the retirees. However, it should be noted that well-being levels had already been on their postretirement level two years before retirement. The graph suggests the existence of a two year pre-retirement dip in well-being among men who retire so early. Men who retire when they are younger than 60 (top right panel) but not disabled have only very small fluctuations in well-being which are by means statistically significant.

Male respondents who retire between age 60 and 62 also experience a significant increase in well-being in the years following retirement, although the size of the effect is only about half that of the first group (bottom left panel). There is also no pre-retirement dip in subjective well-being.

Finally, the bottom right panel contains the well-being development of normal retirees. Wellbeing levels remain largely the same before and after retirement. It seems as if normal retirement thus as no effect on individual well-being. The slight downward trend is not significant.

Figure 14 contains the results for women. The picture for female early retirees is similar to that for male early retirees: retirement proves to be beneficial for well-being if post-retirement 
years are compared to the year of retirement itself. But if we look back further to three or four years before retirement, we rather get the impression that early retirement is associated with a temporary drop in well-being. In contrast to men, the well-being increase after retirement is not statistically significant. However, this is mainly due to the smaller sample size. Another difference to men is that non-disabled early retirees show very much the same pattern as disabled early retirees. It seems as if these are not really different groups of individuals. We currently have no good explanation for that result.

For women who retire at or after the normal retirement age (60), well-being evolves in a similar same fashion as for their male counterparts. There are a few ups and downs, but no systematic trends. It anything, retirement seems to be slightly beneficial in the first three years after retirement for those who retire at age 60, but the effect is not significant.

<about here Figures 15 and 16>

We now compare early retirees with normal retirees and estimate differences-in-differences. The results are reported in the Figures 15 and 16, again together with their 90\% confidence intervals. The male comparison group are those retiring at age 63-65, The female comparison group are those who retire at age 60 . The differences-in-differences results are not much different than the simple before-after comparisons in the top rows. That was to be expected given the relatively flat well-being profile of normal retirees. The added value is that we have standard errors (or confidence intervals, respectively) for the difference between early and normal retirees. Among men, all three groups of early retirees enjoy larger increases in levels life satisfaction after retirement than normal retirees. The difference is not significant for nondisabled early retirees. Among women, there is a significant decrease in well-being before retirement followed by a non-significant increase after retirement.

The general picture that emerges from our analysis is that early retirement as such seems to be related to subjective well-being, in fact more so than normal retirement. Individuals are generally less happy in the year of retirement than in the years before and after retirement. Early retirement appears to be accompanied by a negative (most probably health-related) shock to well-being but after a short while things go back to normal, i.e. the effect is negative and short-lived rather than positive and long. 


\section{Summary and Conclusion}

The main results of the paper can be summarized as follows: At ages younger than 60 , those who are currently retired are on average much less happy than those still working. The difference is mainly due to a composition effect. Early retirees are mostly people on disability pensions. If disability status is controlled for, the well-being differential between early retirees and those still working vanishes. Thus, it is not retirement as such that reduces life satisfaction but disability.

Those who retire early are on average less happy than those who retire later. This holds at each age, i.e. before, at, and after retirement. In other words: the unhappy retire earlier but they never catch up with the happier ones.

Early retirement (because of disability) increases well-being significantly. Early retirement is more beneficial than normal retirement, but only if post-retirement years are compared to the year of retirement itself. Looking further back reveals that there is a marked drop in life satisfaction in pre-retirement years.

Our conclusion is therefore: Early retirement most probably is a reaction to a health shock. Retirement helps those affected because they attain their pre-retirement satisfaction levels one or two years after retirement. Whether this is an effect of retirement itself or a psychological adaptation is still an open issue. 


\section{References}

Berkel, B., and A. Börsch-Supan (2004), Pension Reform in Germany: The Impact on Retirement Decisions, Finanzarchiv, forthcoming.

Börsch-Supan, A. (2000), A Model under Siege: A Case Study of the Germany Retirement Insurance System, The Economic Journal 110, 24-45

Börsch-Supan, A. and R. Schnabel (1998), Social Security and Declining Labor Force Participation in Germany, American Economic Review 88, 173-178

Börsch-Supan, A., and R. Schnabel (1999), Social Security and Retirement in Germany, in: J. Gruber and D.A. Wise (eds.), Social Security and Retirement Around the World, Chicago, 135-181

Börsch-Supan, A. and C. Wilke (2003), The German Social Security System: How it Was and How it Will Be, MEA-Discussion Paper 43-2003, MEA, Universität Mannheim, and MRRC-Discussion Paper, University of Michigan, Ann Arbor.

Börsch-Supan, A., R. Schnabel, S. Kohnz and G. Mastrobuoni (2004), Micro Modelling of Retirement Choices in Germany, in: J. Gruber und D. Wise (eds.), Social Security Programs and Retirement around the World: Micro-Estimation, Chicago, 285-343.

Börsch-Supan, A. S. Kohnz and R. Schnabel (2004), Budget Effects of Pension Reform in Germany, in: J. Gruber und D. Wise (eds.), Social Security Programs and Retirement around the World: Fiscal Implications, Chicago, in press.

Bound, J. (1991), "Self-Reported Versus Objective Measures of Health in Retirement Models”, Journal of Human Resources 26, 106-138.

Charles, K.K. (2002): Is retirement depressing? Labor force inactivity and psychological wellbeing in later life. NBER Working Paper 9033.

Clark, A.E., Diener, E., Georgellis, Y., Lucas, R.E. (2003), Lags and leads in life satisfaction. A test of the baseline hypothesis, DIW Discussion Paper 371.

Greene W. (2001), Estimating Econometric Models with Fixed Effects, New York University, Mimeo.

Jürges, H. (2003), Age, Cohort, and the Slump in Job Satisfaction among West-German Workers, Labour 17, 489-518.

Landua D. (1993). Veränderungen von Zufriedenheitsangaben in Panelbefragungen. Kölner Zeitschrift für Soziologie und Sozialpsychologie 45, 553-571.

Lindeboom, M., Portrait, F., van den Berg, G.J (2002), An Econometric Analysis of the Mental-Health Effects of Major Events in the Life of Elderly Individuals. Health Economics, 11, 505-520.

Schräpler, J. (2001), Respondent behaviour in panel studies: a case study of the German Socio-Economic Panel. DIW Discussion Paper 244.

Stock, J.H., and Wise, D.A. (1990). 'The Pension Inducement to Retire: An Option Value Analysis.' In: D.A. Wise (ed.) Issues in the Economics of Aging. Chicago: The University of Chicago Press, 205-30.

van Praag, B.M.S. and Baarsma, B.E. (2001), The shadow price of aircraft noise nuisance, Tinbergen Institute Discussion Paper 2001-010/3. 
Winkelmann, L. and Winkelmann, R. (1998), Why are the unemployed so unhappy? Economica 65, 1-15. 
Table 1: Trends in Program Generosity

\begin{tabular}{|l|l|}
\hline Year & Measures Taken/Changes \\
\hline 1972 & $\begin{array}{l}\text { Introduction of several generous early retirement options } \\
\text { - flexible retirement at } 63 \\
\text { - old-age disability pensions at } 62\end{array}$ \\
1984 & $\begin{array}{l}\text { Gross } \text { wage indexation suspended for several years } \\
\text { Eligibility requirements reduced from } 15 \text { to } 5 \text { contribution years } \\
\text { Restrictions on disability pensions eligibility } \\
\text { Change from gross to net wage indexation } \\
\text { Several long-run changes not yet fully phased in } \\
\text { - actuarial fairness } \\
\text { - regular retirement age for women increases from } 60 \text { to } 65\end{array}$ \\
since 2001 & \begin{tabular}{l} 
Add indexation to system dependency ratio and several other changes \\
\hline
\end{tabular} \\
\hline
\end{tabular}




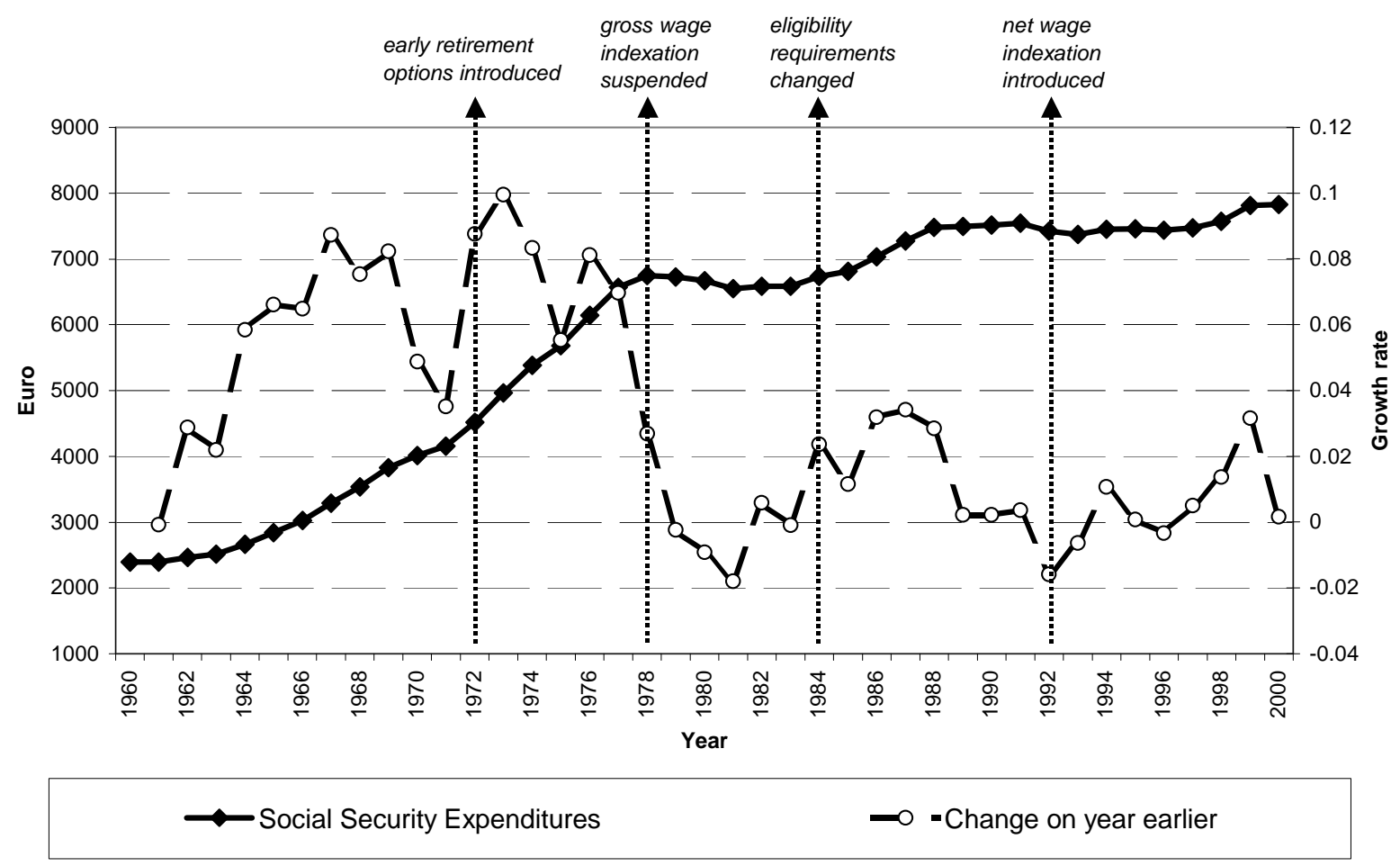

Figure 1: Changes in program generosity and social security expenditures 
Table 2: Data Sources for key well-being dimensions

\begin{tabular}{|c|c|c|c|c|c|}
\hline Dimension & Data Source & Level & Available Years & Type & $\begin{array}{l}\text { Approx. } \\
\text { Sample } \\
\text { Size }\end{array}$ \\
\hline Income & GSOEP & $\mathrm{I}, \mathrm{HH}$ & 1984-today & Panel & 10,000 ind. \\
\hline Expenditures & EVS & $\mathrm{HH}$ & $\begin{array}{l}\text { 1978, 1983, 1988, } \\
1993,1998\end{array}$ & $\begin{array}{l}\text { Cross- } \\
\text { Sections }\end{array}$ & 40,000 hh. \\
\hline $\begin{array}{l}\text { Subjective } \\
\text { Well-being }\end{array}$ & $\begin{array}{l}\text { GSOEP } \\
\text { Welfare Survey } \\
\text { Eurobarometer }\end{array}$ & $\begin{array}{l}\text { I } \\
\text { I } \\
\text { I }\end{array}$ & $\begin{array}{l}\text { 1984-today } \\
\text { 1978, 1980, 1984, } \\
\text { 1988, 1993, } 1998 \\
\text { 1973-today } \\
\text { (with gaps) }\end{array}$ & $\begin{array}{l}\text { Panel } \\
\text { Cross- } \\
\text { Sections } \\
\text { Cross- } \\
\text { Sections }\end{array}$ & $\begin{array}{l}\text { 10,000 ind. } \\
2,000 \text { ind. } \\
1,000 \text { ind. }\end{array}$ \\
\hline $\begin{array}{l}\text { Self-reported } \\
\text { health }\end{array}$ & GSOEP & $\mathrm{I}$ & 1992-today & Panel & 10,000 ind. \\
\hline Mortality & StaBu Life Tables & & 1950-today & Aggregate & n.a. \\
\hline
\end{tabular}


Table 3: Numbers of observations, by year, sex, and labor force status

\begin{tabular}{|l|l|l|l|l|}
\hline & men & \multicolumn{3}{l|}{ women } \\
\cline { 2 - 5 } Year & not retired & retired & not retired & retired \\
\hline 1984 & 449 & 19 & 219 & 10 \\
1985 & 442 & 70 & 242 & 19 \\
1986 & 450 & 114 & 262 & 35 \\
1988 & 473 & 154 & 282 & 50 \\
1989 & 486 & 182 & 295 & 70 \\
1990 & 498 & 208 & 295 & 92 \\
1991 & 502 & 241 & 299 & 116 \\
1992 & 465 & 292 & 297 & 135 \\
1993 & 428 & 322 & 273 & 157 \\
1994 & 398 & 342 & 256 & 168 \\
1995 & 376 & 355 & 237 & 195 \\
1996 & 341 & 352 & 193 & 214 \\
1997 & 302 & 371 & 182 & 225 \\
1998 & 249 & 373 & 152 & 240 \\
1999 & 189 & 372 & 118 & 246 \\
2000 & 143 & 401 & 99 & 252 \\
2001 & 80 & 410 & 58 & 274 \\
2002 & 38 & 406 & 25 & 281 \\
\hline
\end{tabular}


Table 4: Retirement age and pension types for different subgroups (number of individuals in each group in parentheses)

\begin{tabular}{|l|c|c|}
\hline & Men & Women \\
\hline Disability pensions (DI) & Age 55-59 & Age 55-59 \\
& $(\mathrm{N}=120)$ & $(\mathrm{N}=40)$ \\
Other early retirement & Age 55-59 & Age 55-59 \\
& $(\mathrm{N}=91)$ & $(\mathrm{N}=51)$ \\
Old-age pensions after unemployment / disability & Age 60-62 & \\
& $(\mathrm{N}=384)$ & Age 60 \\
Old-age pensions & Age 63-65 & $(\mathrm{N}=207)$ \\
& $(\mathrm{N}=204)$ & Age 61-65 \\
Old-age pensions (short employment history) & & $(\mathrm{N}=136)$ \\
\hline
\end{tabular}



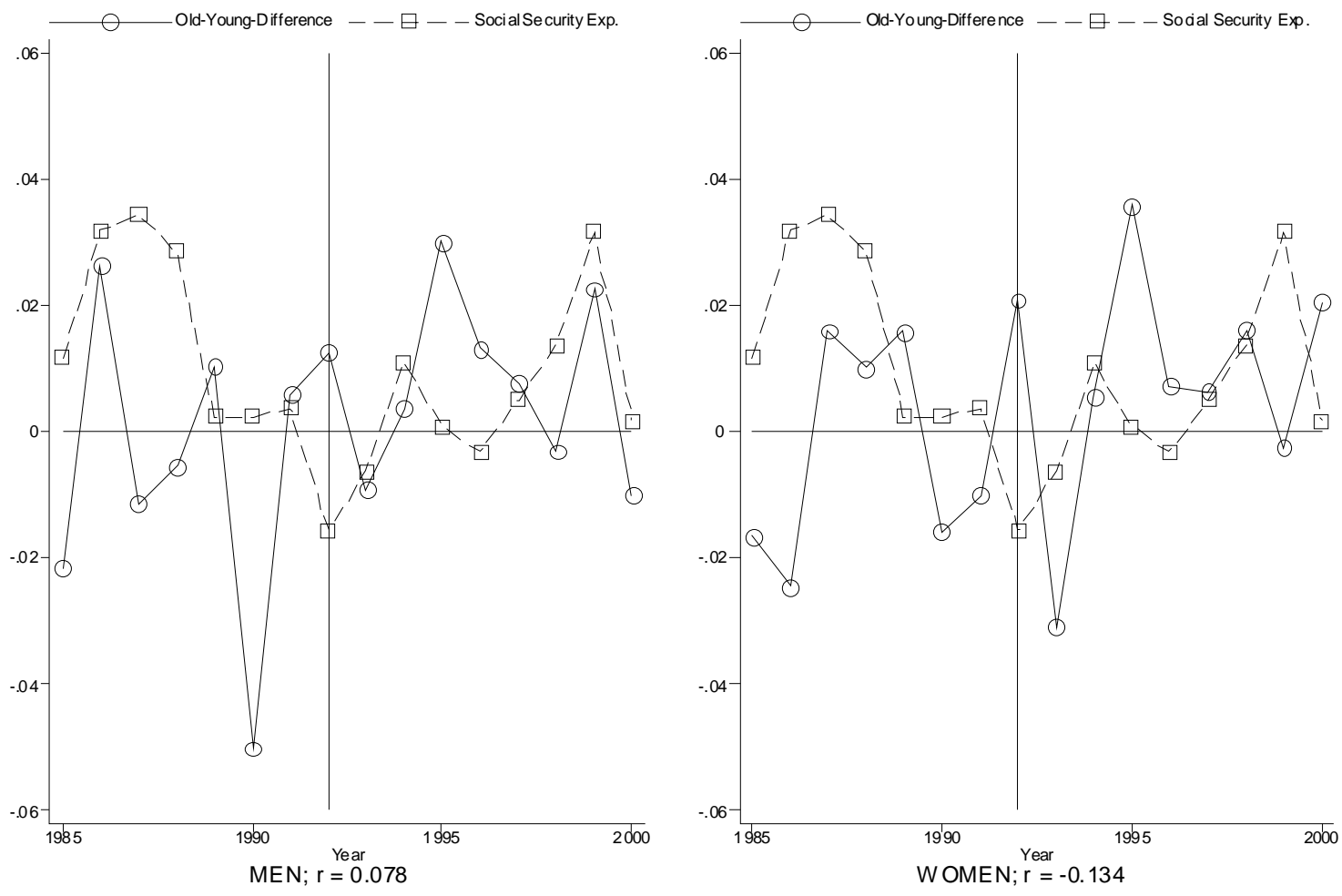

Figure 2: Social security expenditures growth and relative income growth of the elderly 


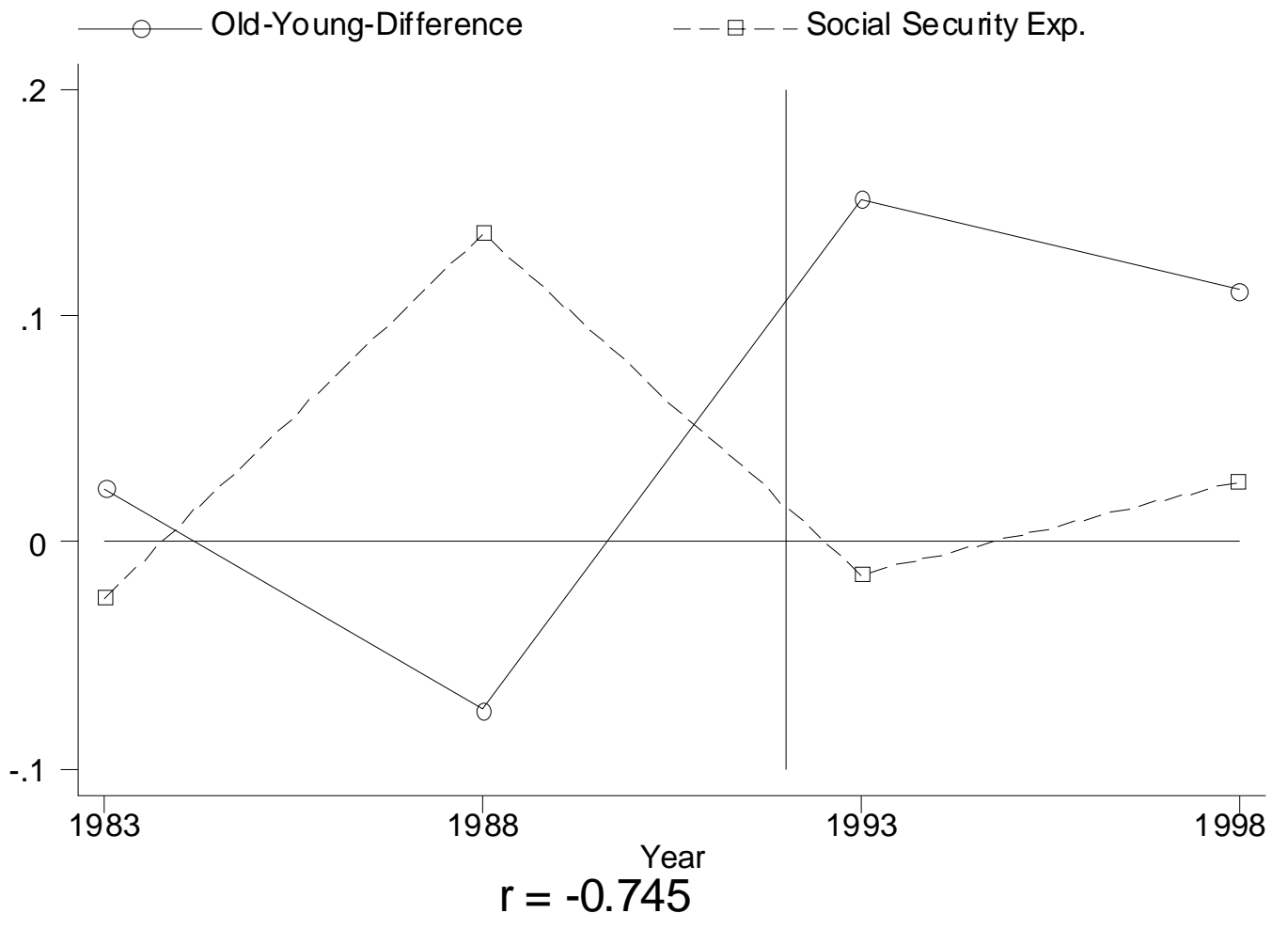

Figure 3: Social security expenditures growth and relative expenditure growth of the elderly 


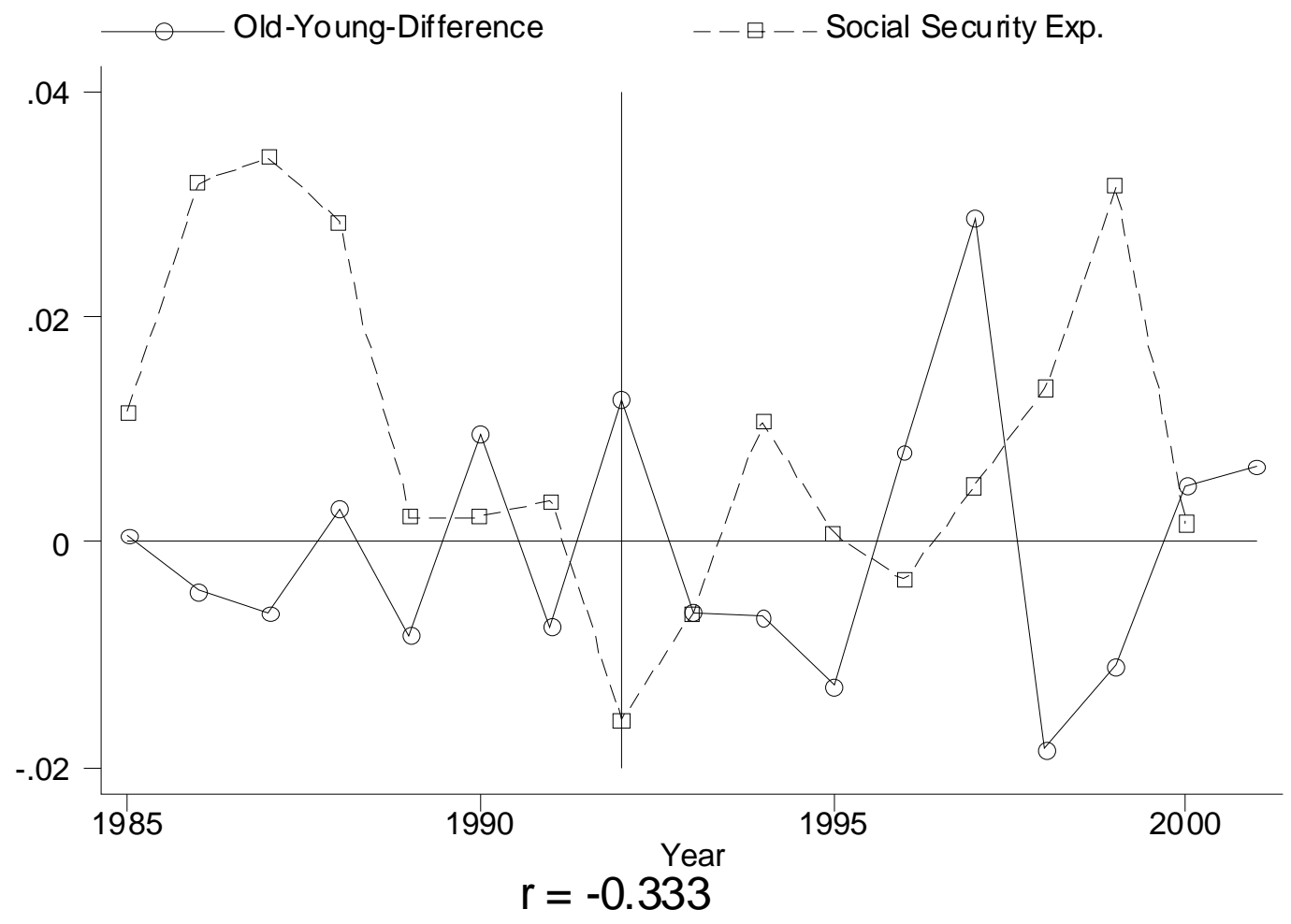

Figure 4: Social security expenditures growth and relative poverty rates of the elderly 


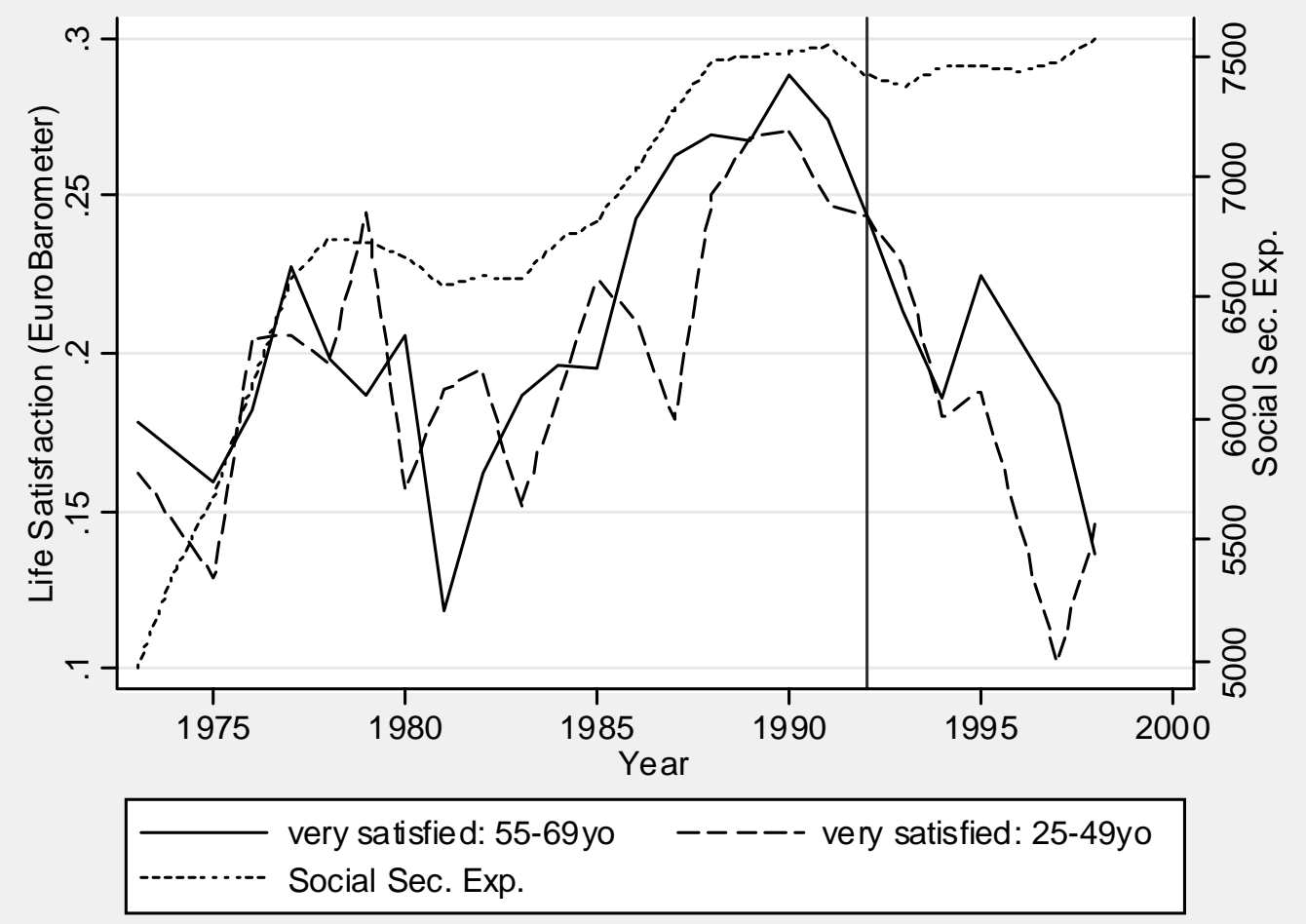

Figure 5: Social security expenditures and well-being (Eurobarometer) 


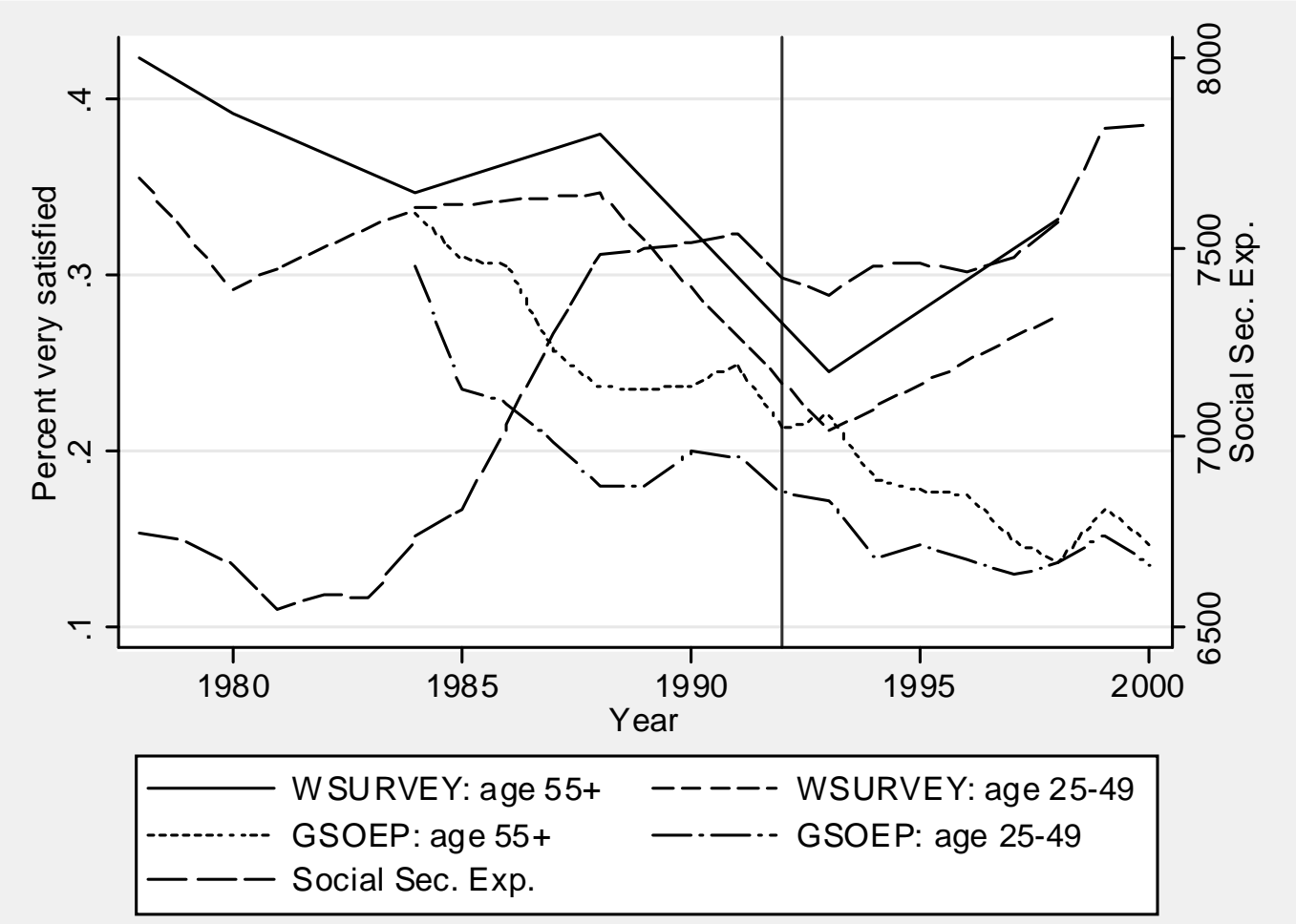

Figure 6: Social security expenditures and well-being (Welfare Surveys and GSOEP) 


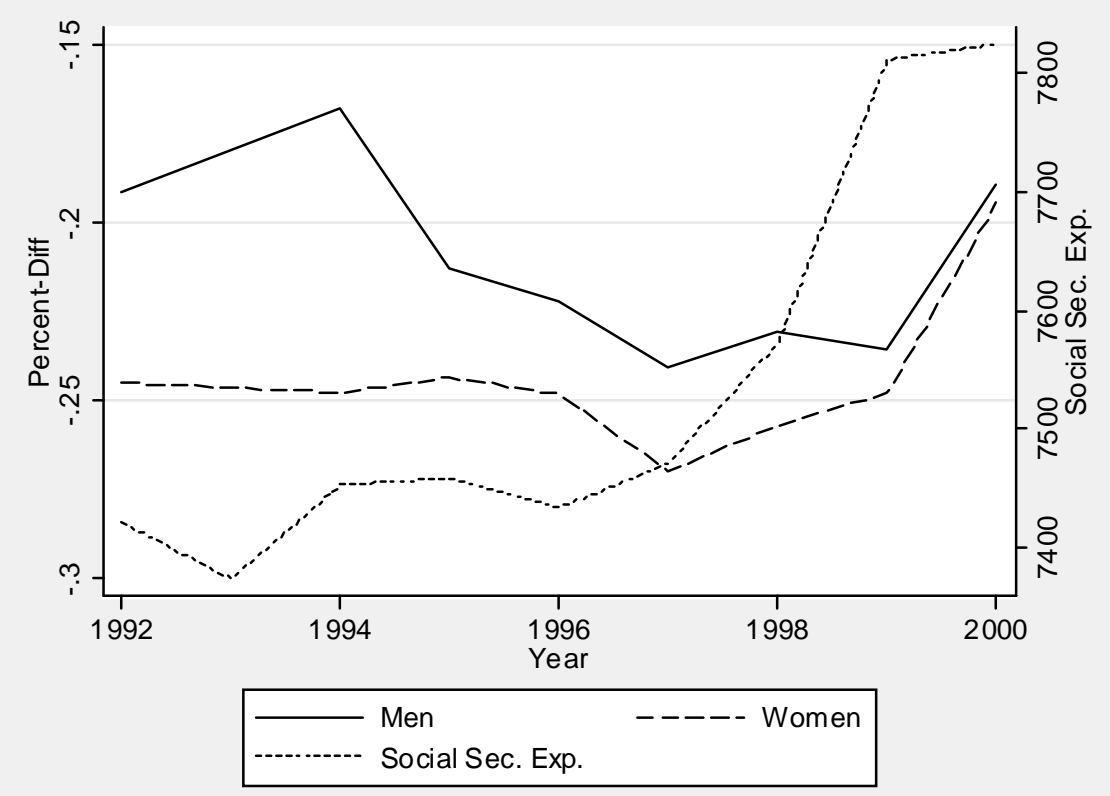

Figure 7: Social security expenditures and self-reported general health 

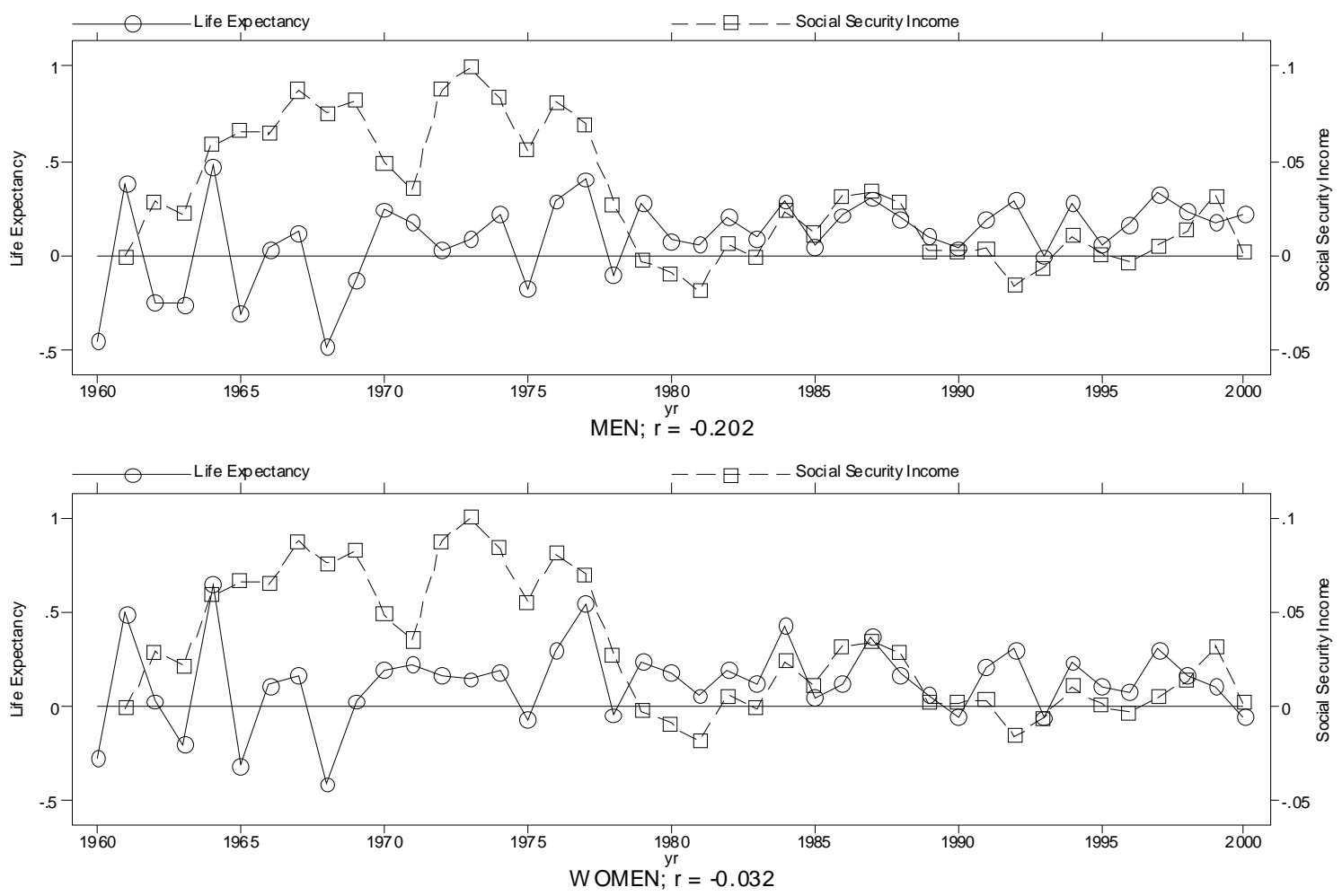

Figure 8: Social security expenditures changes and life expectancy changes 

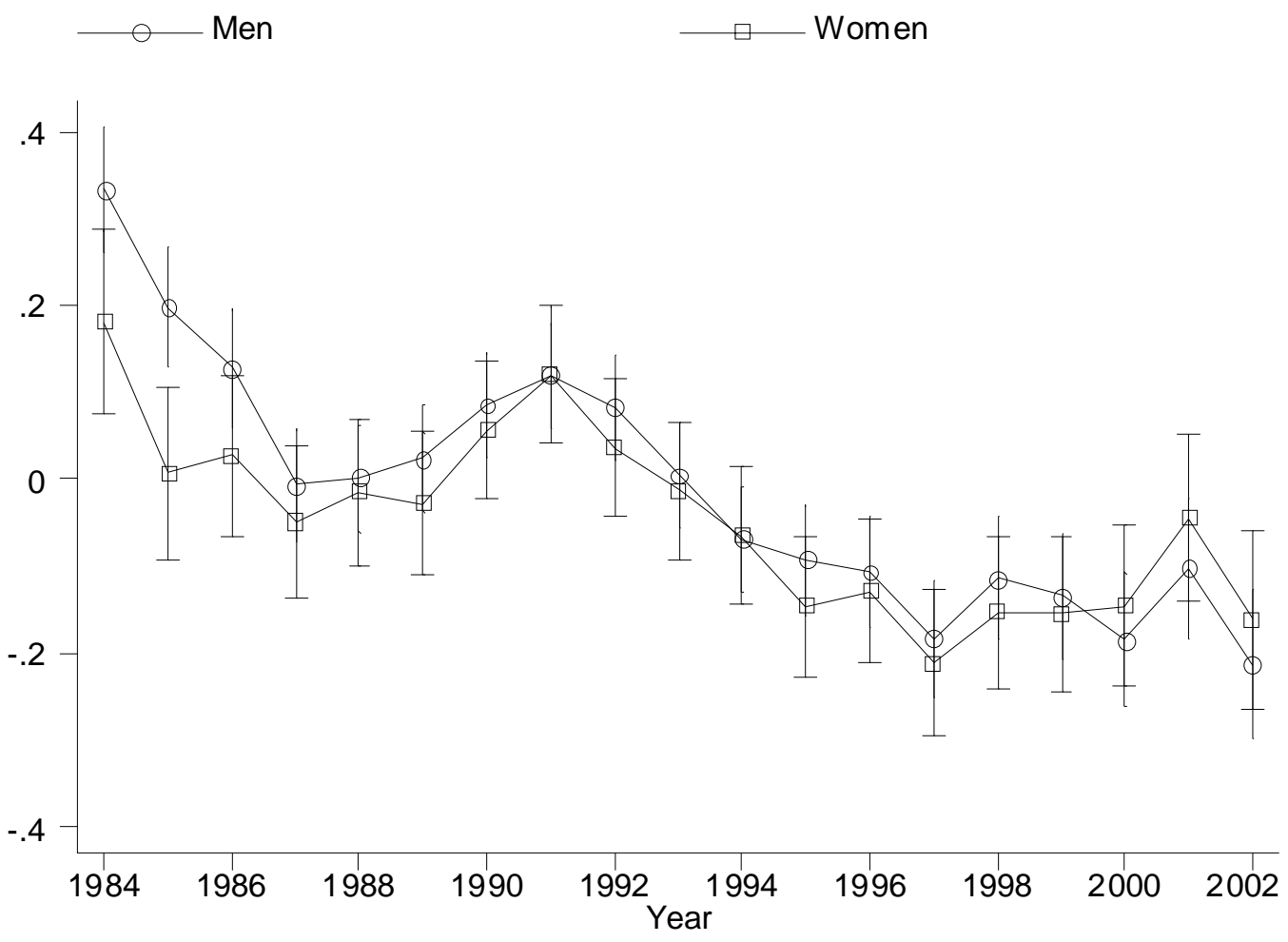

Figure 1: Subjective well-being (by year and sex) 


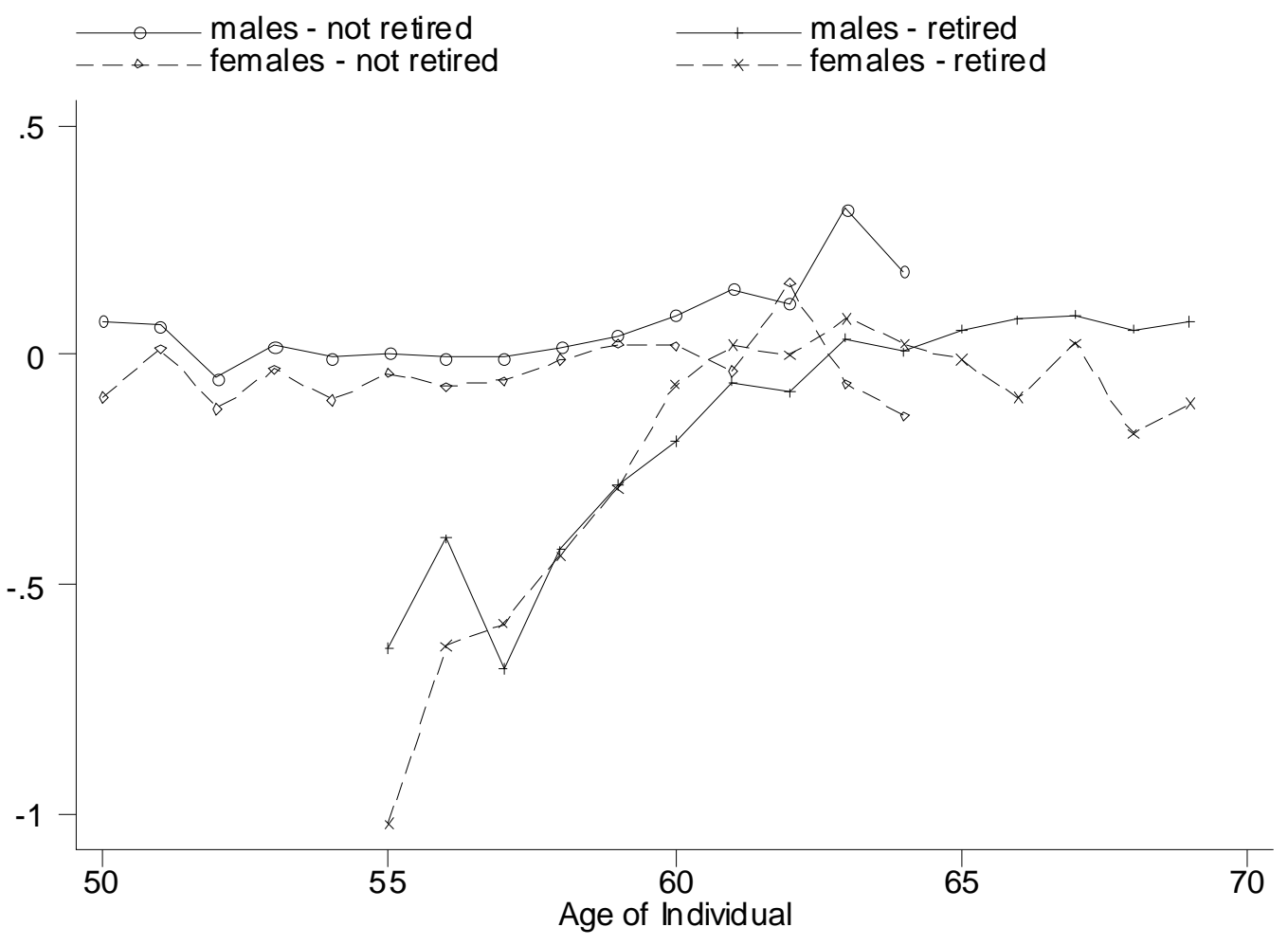

Figure 10: Age trends in average life satisfaction (by sex and retirement status) 

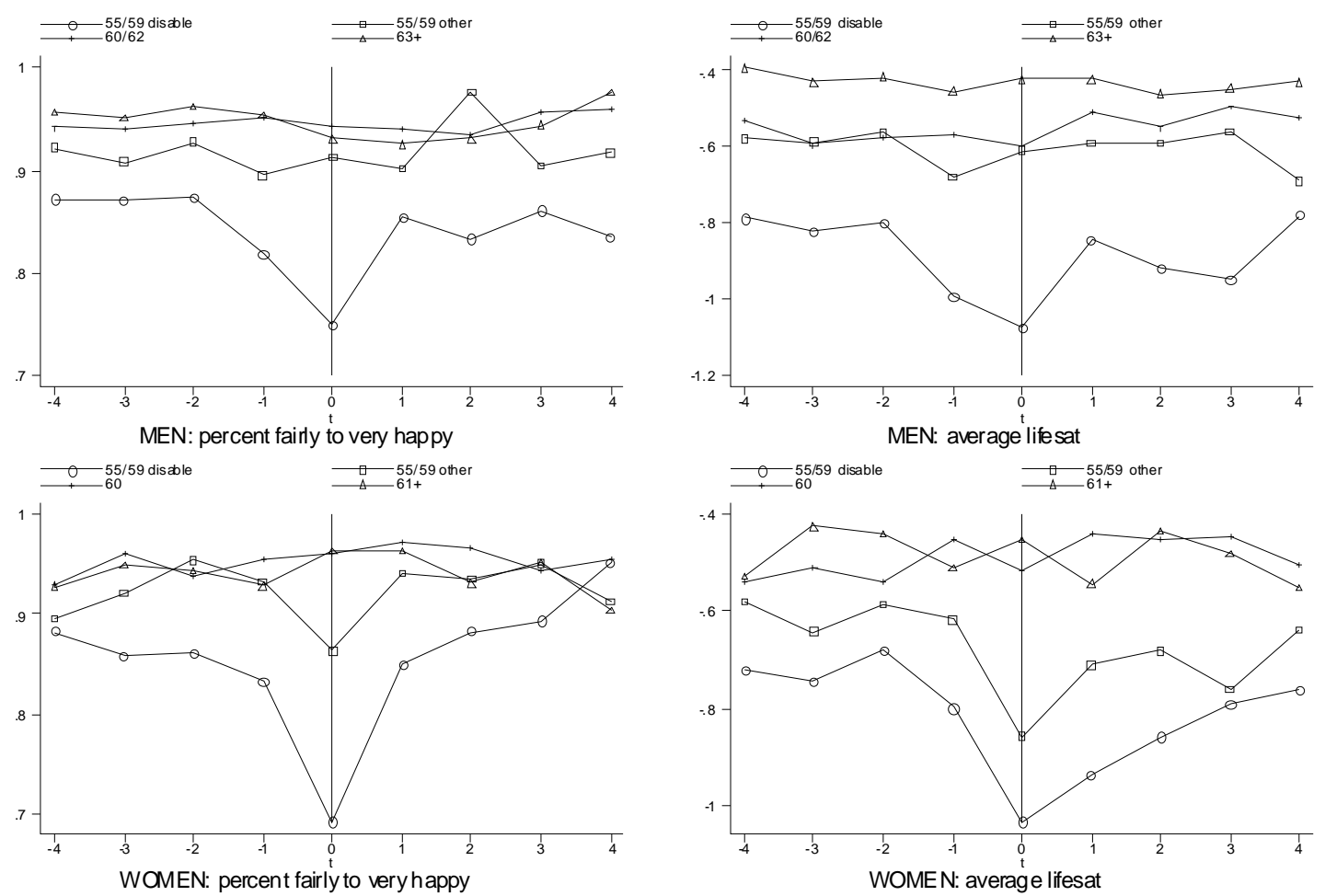

Figure 11: Proportion of fairly to very happy respondents and average life satisfaction before and after retirement. Upper row men, lower row women. 

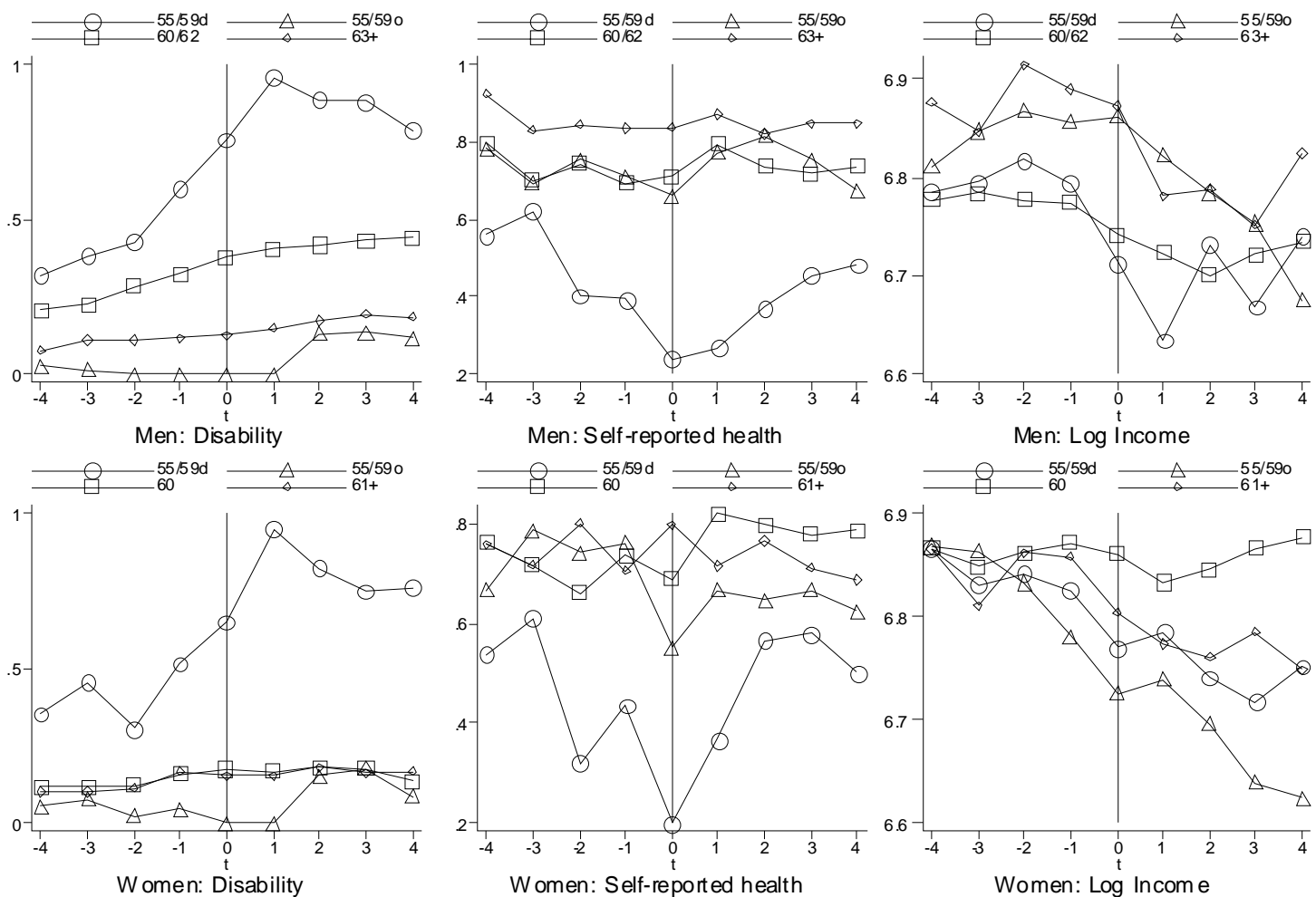

Figure 12: Legal disability, self-reported health, and per capita household income before and after retirement. 

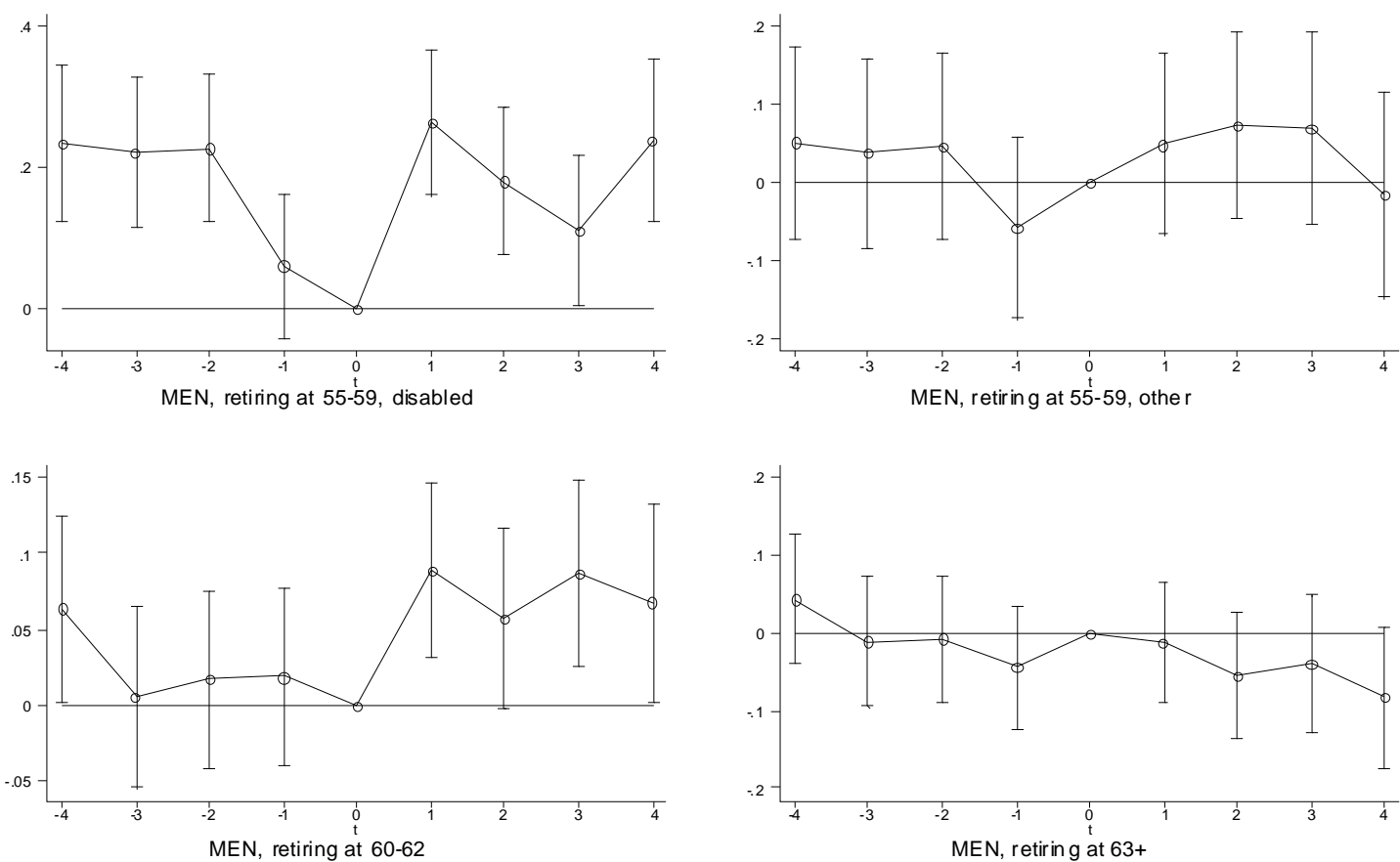

Before-After Comparison

Figure 13: Fixed-effects estimates of average life satisfaction, before and after retirement, men (by retirement age, with $90 \%$ confidence interval) 

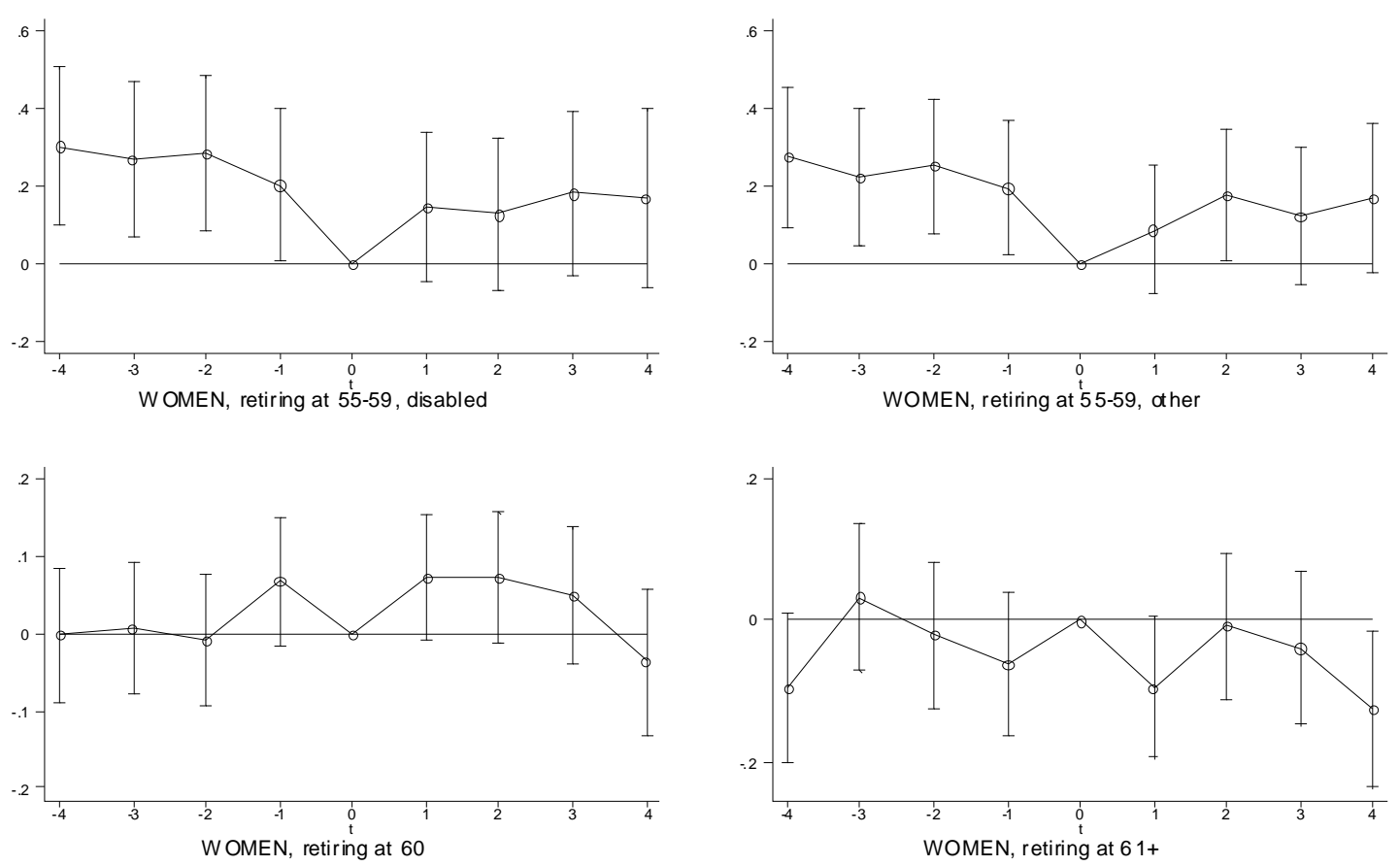

Before-After Comparison

Figure 14: Fixed-effects estimates of average life satisfaction, before and after retirement, women (by retirement age, with $90 \%$ confidence interval) 

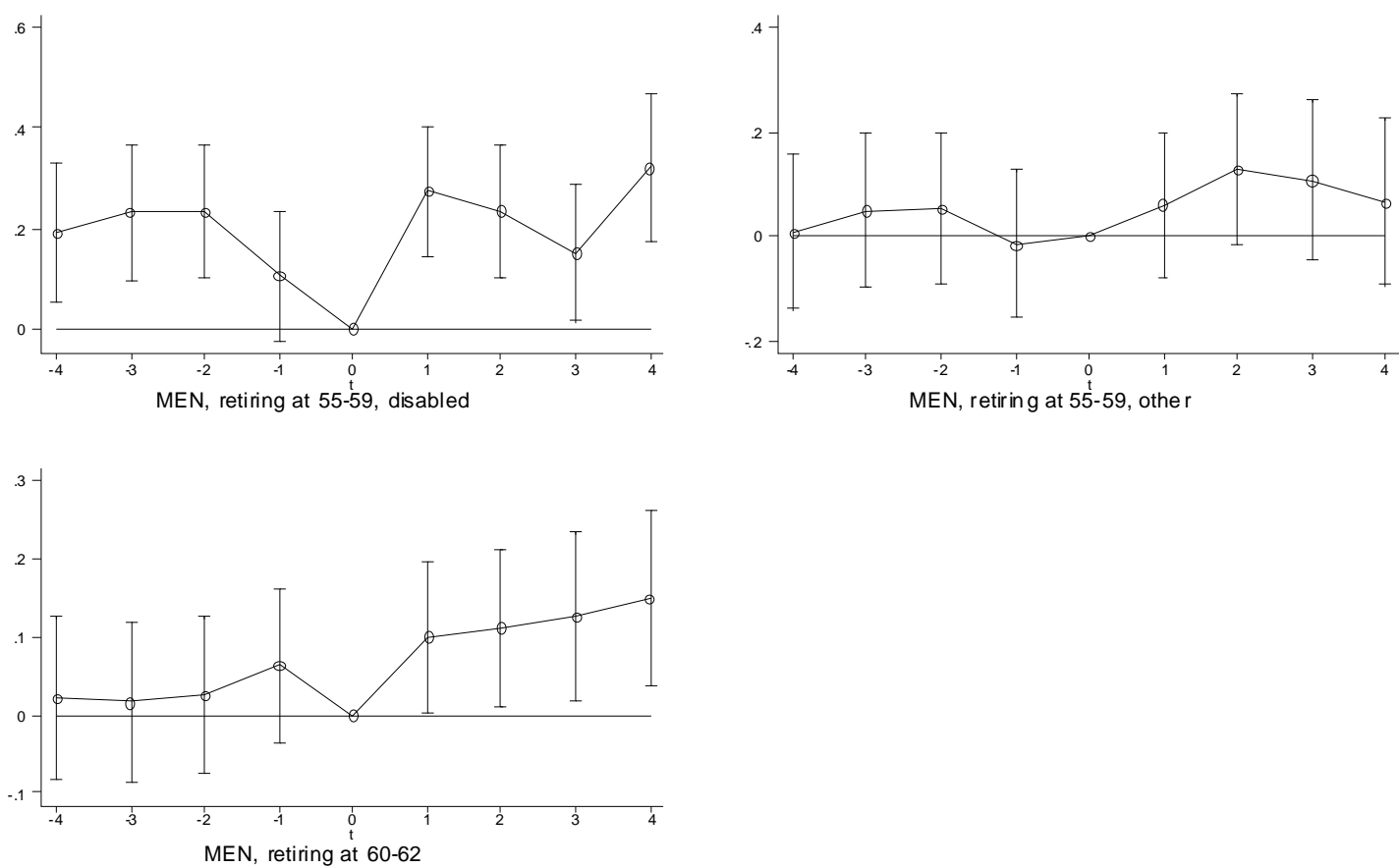

\section{Differences-in-Differences}

Figure 15: Difference-in-Differences estimates of average life satisfaction, before and after retirement, men (by retirement age, with $90 \%$ confidence interval) 

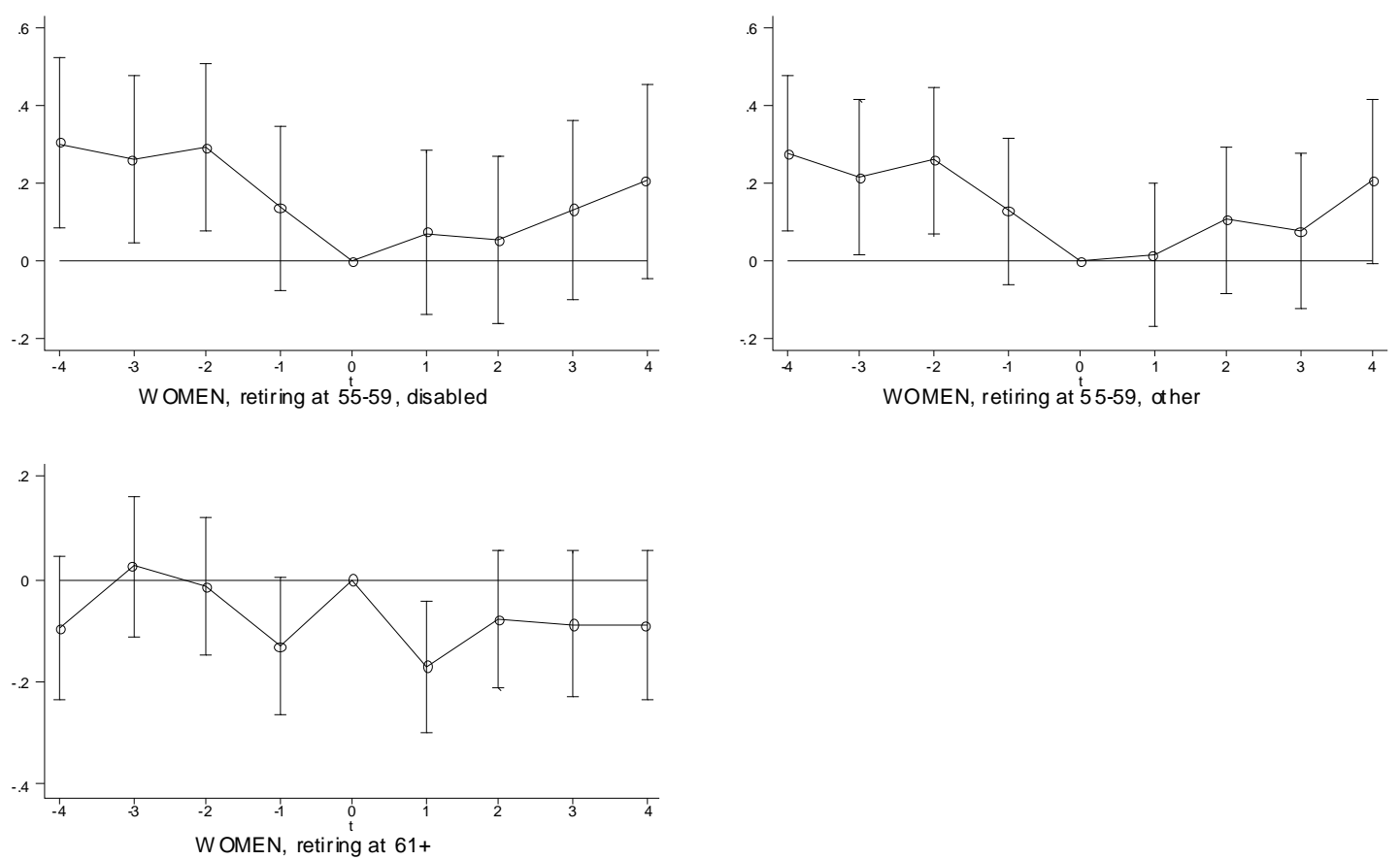

\section{Differences-in-Differences}

Figure 16: Difference-in-Differences estimates of average life satisfaction, before and after retirement, women (by retirement age, with $90 \%$ confidence interval) 


\section{Discussion Paper Series}

Mannheim Research Institute for the Economics of Aging Universität Mannheim

To order copies, please direct your request to the author of the title in question.

\begin{tabular}{|c|c|c|c|}
\hline Nr. & Autoren & Titel & Jahr \\
\hline $122-07$ & Matthias Sommer & $\begin{array}{l}\text { Fiskalische Auswirkungen einer Erweiterung des } \\
\text { Förderrahmens von Riesterrenten }\end{array}$ & 07 \\
\hline $123-07$ & $\begin{array}{l}\text { Karsten Hank } \\
\text { Stephanie Stuck }\end{array}$ & $\begin{array}{l}\text { Ehrenamt, Netzwerkhilfe und Pflege in Europa - } \\
\text { Komplementäre oder konkurrierende } \\
\text { Dimensionen produktiven Alterns? }\end{array}$ & 07 \\
\hline $124-07$ & Daniel Schunk & $\begin{array}{l}\text { What Determines the Saving Behavior of } \\
\text { German Households? An Examination of Saving } \\
\text { Motives and Saving Decisions }\end{array}$ & 07 \\
\hline $125-07$ & Matthias Sommer & & 07 \\
\hline $126-07$ & $\begin{array}{l}\text { Axel H. Börsch-Supan, } \\
\text { Anette Reil-Held, } \\
\text { Christina B. Wilke }\end{array}$ & $\begin{array}{l}\text { How an Unfunded Pension System looks like } \\
\text { Defined Benefits but works like Defined } \\
\text { Contributions: The German Pension Reform }\end{array}$ & 07 \\
\hline $127-07$ & $\begin{array}{l}\text { Karsten Hank } \\
\text { Isabella Buber }\end{array}$ & $\begin{array}{l}\text { Grandparents Caring for Their Grandchildren: } \\
\text { Findings from the } 2004 \text { Survey of Health, } \\
\text { Ageing and Retirement in Europe }\end{array}$ & 07 \\
\hline $128-07$ & Axel Börsch-Supan & $\begin{array}{l}\text { European welfare state regimes and their } \\
\text { generosity towards the elderly }\end{array}$ & 07 \\
\hline $129-07$ & $\begin{array}{l}\text { Axel Börsch-Supan } \\
\text { Alexander Ludwig } \\
\text { Mathias Sommer }\end{array}$ & Aging and Asset Prices & 07 \\
\hline $130-07$ & Axel Börsch-Supan & $\begin{array}{l}\text { Nachfrageseitiger Wettbewerb im } \\
\text { Gesundheitswesen }\end{array}$ & 07 \\
\hline $131-07$ & \begin{tabular}{|l} 
Florian Heiss, Axel \\
Börsch-Supan, Michael \\
Hurd, David Wise
\end{tabular} & $\begin{array}{l}\text { Pathways to Disability: Predicting Health } \\
\text { Trajectories }\end{array}$ & 07 \\
\hline $132-07$ & Axel Börsch-Supan & Rational Pension Reform & 07 \\
\hline $133-07$ & Axel Börsch-Supan & Über selbststabilisierende Rentensysteme & 07 \\
\hline $134-07$ & $\begin{array}{l}\text { Axel Börsch-Supan, } \\
\text { Hendrik Jürges }\end{array}$ & $\begin{array}{l}\text { Early Retirement, Social Security and Well- } \\
\text { Being in Germany }\end{array}$ & 07 \\
\hline
\end{tabular}

